AperTO - Archivio Istituzionale Open Access dell'Università di Torino

Long-term eruptive trends from space-based thermal and SO2emissions: a comparative analysis of Stromboli, Batu Tara and Tinakula volcanoes

This is a pre print version of the following article:

Original Citation:

Availability:

This version is available http://hdl.handle.net/2318/1684782

since 2018-12-18T14:33:33Z

Published version:

DOI:10.1007/s00445-018-1242-0

Terms of use:

Open Access

Anyone can freely access the full text of works made available as "Open Access". Works made available under a Creative Commons license can be used according to the terms and conditions of said license. Use of all other works requires consent of the right holder (author or publisher) if not exempted from copyright protection by the applicable law. 
See discussions, stats, and author profiles for this publication at: https://www.researchgate.net/publication/326959591

\section{Long-term eruptive trends from space-based thermal and SO2 emissions: a comparative analysis of Stromboli, Batu Tara and Tinakula volcanoes}

Article in Bulletin of Volcanology · September 2018

DOI: 10.1007/s00445-018-1242-0

CITATIONS

READS

0

115

5 authors, including:

Marco Laiolo

University of Florence; Univeristy of Turin

48 PUBLICATIONS 480 CITATIONS

SEE PROFILE

Francesco Massimetti

Università degli Studi di Torino

7 PUBLICATIONS 3 CITATIONS

SEE PROFILE

Corrado Cigolini

Università degli Studi di Torino

80 PUBlicATIONS 914 CITATIONS

SEE PROFILE

Maurizio Ripepe

University of Florence

264 PUBLICATIONS 5,512 CITATIONS

SEE PROFILE

Some of the authors of this publication are also working on these related projects:

Secondary Metabolites, Human Homeostasis and Health View project

Multidisciplinary approach of geothermal prospection in the Argentera Massif (South-Western Alps) View project 

a comparative analysis of Stromboli, Batu Tara and Tinakula volcanoes

61 - Dipartimento di Scienze della Terra, Università di Firenze, V. G. La Pira 4, 50121 Firenze

72 - Dipartimento di Scienze della Terra, Università di Torino, Via Valperga Caluso 35, 10125

8 Torino

9

10 Corresponding Author: Marco Laiolo

11 Email address: marco.laiolo@unito.it

12 ORCID-ID: 14013461100

13

14 Keywords

15 Stromboli twins; MODIS; OMI; Volcanic Radiative Power; gas/magma balance; magma budget

16

17

18

19

20

21

22

23 
25 Batu Tara (Indonesia) and Tinakula (Solomon Island) are two poorly known volcanoes with morphologies and short-term eruptive activity similar to Stromboli (Italy). However, quantitative

27 information about their long-term eruptive behaviours are limited, making the comparisons with

28 Stromboli descriptive and based on short periods of observations. Here, we use over a decade of satellite data to measure and compare the radiant flux (2000-2017) and the $\mathrm{SO}_{2}$ mass (2004-2017)

30 of all three volcanoes. The combined analysis of Volcanic Radiant Power (from MODIS data) and

$31 \mathrm{SO}_{2}$ flux (from OMI data) reveals different long-term eruptive trends and contrasting ratios of $32 \mathrm{SO}_{2}$ /VRP. These data indicate that the eruptive mechanisms operating at each volcano are quite different. The persistent open-vent activity of Stromboli volcano is episodically interrupted by flank eruptions that drain degassed magma stored in the very shallow portion of the central conduit.

35 In contrast, a long-lasting exponential decay of both VRP and $\mathrm{SO}_{2}$ flux observed at Batu Tara is consistent with the eruption of undegassed magma from a deep, closed magma chamber. Finally,

37 Tinakula displays multiple year-long eruptive phases, characterised by evolving gas/thermal ratios and an eruptive intensity increasing with time. Magma budget calculations for this volcano are 39 consistent with eruptionfrom a volatile-zoned magma chamber, coupled with periods of gas/magma accumulations at depth. Our results suggest that the combined analysis of satellite

41 thermal/gas data is a valuable tool for decrypting the long-term volcanic dynamics that could 42 remain hidden over shorter time-scales. 


\section{Introduction}

48 Satellite instruments represent an invaluable resource for measuring eruptive activity at remote volcanoes. In particular, they are unique in providing three main types of datasets, namely: thermal

50 (radiant) flux (e.g. Ramsey and Harris 2013; Wright et al., 2015; Coppola et al. 2016a), gas $\left(\mathrm{SO}_{2}\right)$

51 flux (e.g. Fioletov et al. 2016; Flower et al. 2016; Carn et al. 2017), and deformation (e.g. Biggs

52 et al. 2014; McCormick-Kilbride et al. 2016; Biggs and Pritchard 2017). Data collected from

53 spaceprovide safe, continuous and homogeneous datasets to enable long-term observations of 54 global volcanic activity and detection of volcanic unrest at poorly-monitored volcanoes (e.g. 55 Wright et al. 2005; Chaussard et al. 2013; Coppola et al. 2015). While satellite data are becoming an essential input for real-time volcano hazard assessment (e.g. Ganci et al. 2012; Pyle et al. 2013;

57 Harris et al. 2017), their back-analysis also permits the recognition of eruptive trends and patterns 58 otherwise impossible at volcanoes lacking a ground-based monitoring network (e.g. Coppola et al. 59 2017a; Dean et al. 1998; Flower et al. 2016). Moreover, the growing databases of remote sensed 60 data allows reconstruction emission of deformation histories, essentially at each volcano on earth, 61 and permit a direct comparison between different volcanoes, both at local and global scales (cf. 62 Harris 2013; Wright et al. 2015; Biggs and Pritchard 2017; Carn et al. 2017).

63 Batu Tara $\left(7.792^{\circ} \mathrm{S}, 123.579^{\circ} \mathrm{E}\right)$ and Tinakula $\left(10.38^{\circ} \mathrm{S}, 165.8^{\circ} \mathrm{E}\right)$ are two remote, unmonitored, 64 active volcanoes located in the Lesser Sunda archipelago (Indonesia) and Solomon Islands, 65 respectively (Fig. 1). They have a remarkable resemblance to the well-studied Stromboli $66\left(38.789^{\circ} \mathrm{N}, 15.213^{\circ} \mathrm{E}\right)$ volcano (Italy), a feature that has earned them the titles of "Stromboli of the 67 Banda Sea", or "Stromboli of the Solomon Islands", or more generally "Stromboli twins" (Batu 68 Tara and Tinakula Global Volcanism Program main pages, 69 https://volcano.si.edu/volcano.cfm?vn=264260, https://volcano.si.edu/volcano.cfm?vn=256010). 
This similarity derives from the evident morpho-structural similarity of the islands (Fig. 2), as well

71 as from the rare field observations (Gaudin et al. 2017) and reports (Rothery et al. 2005) that

72 describe their main activity as "strombolian" (that is characterised by persistent degassing and

73 intermittent mild explosions; see Barberi et al. 1993).

74 However, the absence of in-situ monitoring instruments, as well as the difficulties of reaching and

75 landing on the islands, make measurements sporadic, with only very few studies focused on the 76 description and characterisation of their eruptive activity (Rothery et al. 2005; Gaudin et al. 2017).

77 Consequently, Tinakula and Batu Tara volcanoes have had low scientific coverage (one and seven 78 papers, respectively) compared to Stromboli whose evolution, structure and eruptive dynamic is 79 much more studied (more than 800 papers based on Scopus database since 1980, 80 https://www.scopus.com). It is thus clear that a rigorous and long-term analysis of the eruptive 81 activity characterising Batu Tara and Tinakula is still lacking, making the comparison with 82 Stromboli purely descriptive and based exclusively on short-term behaviours (i.e., on the scale of 83 single explosive event(s); Gaudin et al. 2017).

84 In this paper we characterise, the long-term thermal and degassing activity (2000-2017) of Batu 85 Tara, Tinakula and Stromboli volcanoes by using satellite data acquired by three different sensors. 86 To track and quantify the radiant heat flux, in terms of Volcanic Radiative Power (VRP in Watt), 87 at each volcano, we used the Moderate Resolution Imaging Spectroradiometer (MODIS) data. The 88 location and extension of the thermal anomalies have been constrained by using thermal images 89 collected by the Advanced Spaceborne Thermal Emission and Reflection Radiometer (ASTER). 90 Data acquired by the Ozone Measurement Instrument (OMI) were used to estimate the daily $\mathrm{SO}_{2}$ 91 flux ( $\phi \mathrm{SO}_{2}$ in Tonnes/day) associated with the volcanic gas emissions. Whilst for Batu Tara, 92 Tinakula volcanoes these space-based data sets represent a unique source of information, here we 
used Stromboli volcano as a benchmark for satellite data, because of the substantial understanding

94 of its plumbing system and eruptive mechanisms (e.g. Allard et al. 1994; Aiuppa et al. 2010;

95 Métrich et al. 2009; Ripepe et al. 2008, 2015).

96 Previous works successfully adopted similar combinations of thermal and degassing

97 measurements, to provide insight into the geometry of the plumbing systems and investigate the

98 balance between exogenous versus endogenous growth (e.g. Harris and Stevenson 1997; Steffke et al. 2011; Koeppen et al. 2011; Barrière et al. 2017; Coppola et al. 2016b; 2017a; Aiuppa et al.

100

101

102

103

104

105

106

107

108

109

110

111

112

113

114

115

2018). In fact, the radiant flux sourced by effusive activity can be used to constrain the lava discharge rate (e.g. Harris et al. 1998; Harris et al. 2007; Coppola et al., 2013), as well as to infer the rate at which the magma circulate at superficial levels, at open-vent volcanoes (e.g. Francis et al. 1993; Oppenheimer et al. 2004; Aiuppa et al. 2018). At the same time, the $\mathrm{SO}_{2}$ flux from a volcanic vent is widely used to determine the rate at which magma is supplied to shallow levels and degas (e.g. Allard et al. 1994; Francis et al. 1993; Andres and Kasgnoc 1998; Shinohara 2008). Hence, coeval thermal and gas measurements can be used to investigate the magma-gas differentiation processes and to address the occurrence of the so called "excess degassing" (i.e. degassing of unerupted magma with a much larger volume than that of erupted magma), one of the most important concepts in understanding the volatile budget, eruption mechanisms, and differentiation of magmas in the crust (e.g. Allard et al. 1994; Andres and Kasgnoc 1998; Francis et al. 1993; Shinohara 2008).

In the following sections, we firstly describe the main tectonic, geochemical and morphological features of the three volcanoes by outlining similarities and differences from previous works and observations. Then, we present the analysis of 17-year-long records of satellite data acquired over the three volcanoes, in order to: (i) evaluate the persistence and intensity of the volcanic emissions 
116 (thermal and gas), (ii) identify long-term changes in the eruptive behaviours; (iii) evaluate the

117 partitioning between erupted and degassed magma by focussing on the $\phi \mathrm{SO}_{2} / \mathrm{VRP}$ ratio.

118 Despite the qualitative resemblance, our results outline marked differences in the eruptive 119 mechanisms of the three volcanoes, which suggest quite different architectures and development 120 of their respective plumbing systems.

121

122

123

124 125 126 127

\section{Stromboli, Batu Tara and Tinakula volcanoes}

The principal features of the three analysed volcanoes, retrieved from the available literature, are summarised in Table 1. Here, we briefly describe their main similarities and differences based on four main aspects: (i) tectonic setting and geochemistry, (ii) morphology, (iii) eruptive products, and (iv) volcanic activity.

27

\section{Tectonic setting, morphology and erupted products}

The tectonic setting of all three volcanoes is consistent with subduction-related magmatism, variably contaminated by slab-derived fluids and/or crustal materials (Elburg et al. 2004; Schuth et al. 2009) and likely overprinted by rift-type processes (De Astis et al. 2003). Recent erupted products (see Table 1) span High-K calc-alkaline basalts for Stromboli (Landi et al. 2009) to potassic-ultrapotassic tephrites for Batu Tara (Van Bergen et al. 1992) and low-potassic (tholeiitic) basalts for Tinakula (Schuth et al. 2009).

All the three islands represent the emerged parts of volcanic edifices rising approximately 3 to 4 $\mathrm{km}$ above their respective abyssal plains (Table 1). The sub-aerial volcanic cones are characterised by similar volumes (from 1.3 to $3.9 \mathrm{~km}^{3}$ ), elevations (from 748 to $924 \mathrm{~m}$ above sea level) and mean slopes of volcanic flanks (from $22^{\circ}$ to $25^{\circ}$ ). All the three volcanic edifices are truncated by 
139 a horse-shoe shape scar, resulting from major lateral collapses, termed here a Sciara del Fuoco140 type collapse following the local name for the collapse scar on Stromboli (Kokelaar and

141 Romagnoli 1995; Tibaldi 2001). The scars host most of the recent volcanic products, erupted from 142 one or more craters located in their higher portions (Fig. 2). Erupted products at the three volcanoes 143 include lava flows, typical of effusive activity, as well as scoria, bombs and ash, typical of mild to 144 moderate explosive activity (Table 1).

145

146

147 Stromboli is known for its persistent activity over 2 ka (Rosi et al. 2000), characterised by 148

149

150

151

152

153

154 155

\section{Recent activity} continuous degassing at summit vents with scoria, bombs, lapilli and ash ejection that normally occur every 15-20 minutes (Newhall and Self 1982, Barberi et al. 1993; Rosi et al. 2000). Periodically, flank effusive episodes interrupt the explosive summit activity, as observed on 20022003, 2007 and 2014 (Ripepe et al. 2017). Paroxysmal explosions may occasionally occur (e.g., 5 April 2003 and 15 March 2007) resulting from rapid decompression of the plumbing system during effusive eruptions (Calvari et al. 2011; Valade et al. 2016). Volcanogenic tsunamis, which affect the Stromboli coastline, have been also observed and are associated to the opening of lateral eruptive fissures triggering flank failure and collapses (Barberi et al. 1993).

The first historical observations of Batu Tara activity describe continuous effusive activity between 1847-1852 (GVP 2007). Subsequently, the volcano entered in a 155-year period of quiescence until January 2007, when a new eruption began (GVP 2007). According to periodic reports, between 2007 and 2011, an effusive activity was accompanied with strombolian to vulcanian explosions, producing ash-rich plumes that reached altitudes of 2-4 km (GVP 2007, 2011, 2014). During 2014, Batu Tara eruptions were characterised by a low-level explosive 
162 activity dominated by gas-poor and ash-rich emissions (Gaudin et al. 2017). Notably, no further

163 ash plumes and thermal anomalies were reported after October 2016 (GVP 2016).

164 Eruptions of Tinakula volcano have been regularly reported since at least 1768 165 (https://volcano.si.edu/volcano.cfm?vn=256010). The eruptive phases typically last months to 166 years and are often separated by periods of repose lasting years to decades (GVP 2003; Rothery et 167 al. 2005). The 1971 eruptive episode (one of the major eruptions of Tinakula in historical time) 168 was characterised by lava flows and ash-dominated explosive activity, which caused a tsunami 169 that led to the evacuation of the island (GVP 1971). Recent observations suggest the occurrence 170 of strombolian activity at the active summit crater(s), accompanied by glowing ejecta often rolling 171 down the steep slope of the scar (Cook et al. 2012). This mild explosive activity is generally 172 characterised by a Volcanic Explosivity Index (VEI; Newhall and Self 1982) of between 1 and 2, 173 with volcanic plume heights not exceeding $4 \mathrm{~km}$ in altitude (Database Eruption search curated by 174 the Smithsonian Institution Global Volcanism 175 http://volcano.si.edu/search_eruption.cfm). Notably, on 21 October 2017, a short and intense 176 eruptive phase produced an ash and gas plume reaching an altitude of about $10.7 \mathrm{~km}$ above sea 177 level. This unexpected eruption was classified as a VEI 3 explosion (NDMO Report 2017) and 178 represents a major event in the eruptive history of this volcano.

\section{Methods}

181 Here we briefly summarise the methods and analytical procedures used to retrieve the radiant heat 182 flux (VRP), the $\mathrm{SO}_{2}$ flux $\left(\phi \mathrm{SO}_{2}\right)$, and to spatially characterise the thermal anomalies observed at 183 the three volcanoes. 
186 In order to quantify the Volcanic Radiative Power (VRP in Watt) at the three volcanoes we used

187 nighttime data acquires between 2000 and 2017 by the two MODIS instruments. MODIS is a 188 multispectral imager mounted on board of Terra and Aqua NASA's satellites, launched on 189 February 2000 and May 2002, respectively. We used the MODIS Level $1 \mathrm{~B}$ data $\left(1 \mathrm{~km}^{2}\right.$ of 190 resolution in the infrared bands) provided by LANCE-MODIS system (http://lance191 modis.eosdis.nasa.gov/) and elaborated by the MIROVA system (http://www.mirovaweb.it/;

192 Coppola et al. 2016c). MIROVA is an automatic hot spot detection system based on the analysis 193 of Middle InfraRed (MIR) radiation detected by MODIS at $\sim 4 \mu \mathrm{m}$ (channels 21 and 22; see 194 Coppola et al. 2016c). Hence, for any alerted pixel, the VRP is calculated by using the MIR-method 195 proposed by Wooster and coauthors (2003):

$$
V R P_{P I X}=18.9 x A_{P I X} x\left(L_{4 a l e r t}-L_{4 b k}\right)
$$

197 where $\mathrm{A}_{\mathrm{PIX}}, \mathrm{L}_{4 a \mathrm{alet}}$ and $\mathrm{L}_{4 \mathrm{bk}}$ are the pixel area $\left(1 \mathrm{~km}^{2}\right.$ for MODIS $)$, and the spectral radiance at 4 $198 \mu \mathrm{m}$ for the alerted pixel(s) and local background, respectively. When two or more pixels (a cluster 199 of pixels) are detected, the total radiative power is calculated as the sum of each single VRP PIX. 200 According to Wooster and coauthors (2003) the MIR-method provides reliable estimates of radiant 201 power $( \pm 30 \%)$ for hot targets that have an integrated temperature comprised between 600 and 1500 $202 \mathrm{~K}$. It follows that the VRP is appropriate to calculate the heat radiated by the active portions of 203 lava flows, or any other volcanic emitters having a temperature higher than $\sim 300{ }^{\circ} \mathrm{C}$. Errors and 204 limits associated to the MODIS-MIROVA data are described in the Online Resource 1. 
206 The frequency distribution of VRP recorded at the three investigated volcanoes between 20002072017 has been also analysed in order to detect and eventually discriminate thermal regimes 208 associated to distinct types of volcanic activity (Coppola et al. 2012; Coppola and Cigolini 2013).

\section{Location and extension of thermal anomaly using ASTER}

211 The ASTER instrument, on board of Terra's satellite, provides radiance measurements in 14 212 spectral bands, spanning from visible and near infrared (VNIR channels 1 to $3 b$ ), short-wave 213 infrared (SWIR channels 4 to 9) and thermal infrared (TIR channels 10 to 13) wavelengths, with

214 spatial resolutions of 15, 30 and 90 m, respectively (Pieri and Abrams 2004). Since 2008, the 215 SWIR images ceased to be available due to a cooling system malfunction (Ramsey 2016).

216 Unlike MODIS, the acquisition of ASTER images is a scheduled in response to individual 217 acquisition requests, or in emergency response to natural disasters, with a complex scheduling and 218 processing plan based on a scale of priorities (i.e. Expedited Data System EDS; Ramsey 2016). 219 Consequently, ASTER does not necessarily provide systematic observations at all volcanoes, but 220 can be used as a valuable complement to the MODIS (Vaughan et al. 2012; Murphy et al. 2013) 221 or other moderate resolution imagers (Reath et al. 2016).

222 Here we used ASTER Level 1T data (Precision Terrain Corrected Registered At-Sensor Radiance 223 that contains calibrated at-sensor radiance, geometrically corrected and ortorectified into UTM 224 projection. More specifically we analysed selected cloud-free TIR images (channel 13, centred at $225 \sim 11.3 \mu \mathrm{m}$ ), with $90 \mathrm{~m}$ /pixel of spatial resolution, in order to locate the thermal anomalies 226 associated to the activity detected by MODIS at the three volcanoes. Particular emphasis is given 227 in discriminating between summit or lateral thermal anomalies and their association with the VRP 228 measured by MODIS. 
231 OMI is one of the four instruments on board of AURA NASA's satellite, dedicated to monitor 232 solar backscatter radiation over wavelengths spanning from 270 to $500 \mathrm{~nm}$ (visible and ultraviolet). 233 OMI is on orbit since the $1^{\text {st }}$ October 2004 and provides daily global coverage through 14 orbits. 234 Each image has a complete swath of $2600 \mathrm{~km}$ and a nominal pixel spatial resolution of $13 \times 24 \mathrm{~km}$ 235 at nadir. In this work we used the OMISO2 Product Level 2G that provide daily, global maps of $236 \mathrm{SO}_{2}$ vertical column density (in D.U.) at a resolution of $0.125^{\circ} \times 0.125^{\circ}$ (Krotkov et al. 2014). 237 This product is based on the Principal Component Analysis (PCA) algorithm (Li et al. 2017) and 238 provides four estimates $\mathrm{SO}_{2}$ vertical column density, by assuming different centres of mass 239 altitudes (CMAs): at $\sim 0.9 \mathrm{~km}$ (Planetary Boundary Layer, PBL), $\sim 2.5 \mathrm{~km}$ (Lower tropospheric, 240 TRL), $7.5 \mathrm{~km}$ (Middle tropospheric, TRM), and $\sim 17 \mathrm{~km}$ (Lower stratospheric, STL), respectively $241 \quad$ (see Carn et al. 2016).

242 When a volcanic plume is imaged by OMI, the amount (mass) of $\mathrm{SO}_{2}$, hereby defined as $\mathrm{MSO}_{2}$, 243 (in Tonnes), is quantified by using the equation proposed by Krueger et al. (1995),

$$
\mathrm{MSO}_{2}=0.0285 \times \sum_{i=0}^{n} A_{i} S O 2_{i}
$$

245 where $A i$ and $S O 2 i$ represent the area (in $\mathrm{km}^{2}$ ) and the $\mathrm{SO}_{2}$ vertical column density (in D.U.) of 246 each $\mathrm{i}^{\text {th }}$ OMI pixel sampling the volcanic plume (Fig. 3).

247 Conversion of $\mathrm{SO}_{2}$ mass $\left(\mathrm{MSO}_{2}\right)$ into flux $\left(\phi \mathrm{SO}_{2}\right)$ is nontrivial, and requires detailed knowledge 248 of $\mathrm{SO}_{2}$ removal rate into the atmosphere, as well as measurements of the wind field at the time of 249 each image acquisition (Theys et al. 2013). Due to the large amount of images and the different 250 conditions operating on the plumes of the three volcanoes, here we used a simplified approach 
251 (Fioletov et al. 2015) whereby, under steady state emissions, the flux and the mass of $\mathrm{SO}_{2}$ are 252 related by:

254 where $(\tau)$ is the lifetime of $\mathrm{SO}_{2}$ into the atmosphere, assumed equal to 1 day (Beirle et al. 2014)

255 In order to quantify $\phi \mathrm{SO}_{2}$ sourced by Stromboli, Batu Tara and Tinakula, we adopted a manual, 256 contextual procedure that allows discarding anomalous pixels (artefacts) and/or volcanic plumes 257 sourced by neighbour volcanoes. We first cropped a $10^{\circ} \times 10^{\circ}$ latitude-longitude box centred on 258 each investigated volcano (Fig. 3). Hence, we calculated a local, contextual threshold, defined as $259 \mu+3 \sigma$, where $\mu$ and $\sigma$ represent, the mean and the standard deviation of the pixels having $\mathrm{SO}_{2}$ 260 density lower than 1 D.U., respectively. All the pixels exceeding this threshold are thus flagged as $261 \mathrm{SO}_{2}$-contaminated, and grouped into distinct clusters (groups of adjacent pixels). Finally, the 262 visual inspection of all the images allow selecting only the specific clusters which are attributed, 263 by the user, to the volcano of interest.

264 This last step was essential in many cases, where an $\mathrm{SO}_{2}$ plume, located above or in proximity of 265 the target volcano was in reality sourced by a neighbour volcano (Fig. 3). At Stromboli for example 266 an automatic detection of $\mathrm{SO}_{2}$ plumes would had been often triggered by the presence of large $\mathrm{SO}_{2}$ 267 emissions sourced by Mt. Etna drifting toward North (Fig. 3a, d). Similarly, in the Lesser Sunda 268 region, the concurrent activity of several volcanoes located in proximity of Batu Tara (i.e. 269 Lewotolo, Sirung and Egon mainly, located to south of Batu Tara; see Fig. 3b, e) sometimes 270 produced $\mathrm{SO}_{2}$-rich plumes extending over Batu Tara island (Fig. 3e). For these reasons, to obtain 271 the most accurate time-series of $\phi \mathrm{SO}_{2}$ and to avoid false detections, the visual inspection of all 272 OMI images was found to be necessary, particularly for regions with multi-sources from active 273 volcanoes. 
274 According to the typical plume heights reported for the analysed volcanoes (typically less than 5

$275 \mathrm{~km}$ ), the calculation of $\mathrm{MSO}_{2}$ has been retrieved by assuming the PBL and TRL layers only.

276 Notably, is well known that the values recorded at the two selected levels may diverge significantly

277 (Flower et al. 2016). In general, the assumption of locating plume higher than the effective altitude

278 could imply a substantial underestimate (up to 60\%) and, locating the plume at lower altitude than

279 that actually reached typically causes an overestimate greater than 100\% (Hayer et al. 2016).

280

281

\section{Results}

282 In this section, we provide a description of $\mathrm{VRP}$ and $\phi \mathrm{SO}_{2}$ time-series recorded at Stromboli, Batu

283 Tara and Tinakula volcanoes by integrating our satellite data with previous research and/or

284 reported visual observations and scientific communications regarding the investigated volcanoes

285 (e.g. Global Volcanism Program - GVP reports; http://www.volcano.si.edu)

288 The time-series of VRP and $\phi \mathrm{SO}_{2}$ obtained for the three analysed volcanoes over the period 2000 289 and 2017 are shown in Fig. 4. Thermal data recorded for all three volcanoes display a quite similar 290 range of values, with VRP spanning from less than $1 \mathrm{MW}$ to about $1000 \mathrm{MW}$. However, there are 291 differences in the persistence of the thermal anomalies, as well as in the frequency distribution of 292 the data (Fig 4). Thermal detections at Stromboli are essentially continuous (Fig. 4a1) showing a 293 bimodal distribution of VRP with modal values of $\sim 5 \mathrm{MW}$ and $\sim 150 \mathrm{MW}$, respectively (Fig. 4c1). 294 This contrasts with the signal recorded at Batu Tara that is characterised by a single, distinct phase 295 of activity (Fig. 4b1) with a unimodal VRP distribution (mode equal to 40 MW; Fig. 4b3). At 
296 Tinakula, the thermal signals recorded suggest multiple phases of activity (Fig. 4c1) but with a 297 unimodal VRP distribution peaking at 10 MW (Fig. 4c3).

298 The 2004-2017 time-series of $\phi \mathrm{SO}_{2}$ also outline differences between each volcano, both in terms 299 of magnitude and continuity of the emissions. Despite the continuous activity of Stromboli, few 300 low-magnitude emissions are measured by OMI (modal value of 100 tonnes/day, in the PBL; 301 Fig. 4a2, a4), whereas higher magnitude and continuous emissions are recorded from Batu Tara 302 (modal values of 130 to 450 tonnes/day in the TRL and PBL, respectively; cf. Fig. 4b2, b4). 303 Sulphur dioxide emissions recorded at Tinakula essentially mimic the phases of thermal activity, 304 with $\phi \mathrm{SO}_{2}$ modal values of 30 and 100 tonnes/day in the TRL and PBL, respectively (cf. Fig. 4c2, 305 c4). The recent event at Tinakula led to a peak of $\phi \mathrm{SO}_{2}(>10,000$ tonnes/day) recorded in October 306 2017.

Stromboli's radiative flux shows a quite continuous and stable trend with values less than 20-30 MW, interrupted by periods with VRP generally greater than $100 \mathrm{MW}$ and peaking at $4600 \mathrm{MW}$ (Fig. 4a1). Previous work shows that the lower thermal emissions are related to the "normal" mild explosive activity, whereas the high VRP periods coincide with the three effusive flank eruptions

312 (e.g., Calvari et al. 2014; Coppola et al. 2014; Valade et al. 2016; Ripepe et al. 2017). Further 313 episodic measurements greater than 50-100 MW are linked to summit overflows and/or short 314 fountaining episodes that occurred during 2009-2014 (black arrows in Fig. 4a1; cf. Calvari et al. 315 2014; Valade et al. 2016). Notably, our $\phi \mathrm{SO}_{2}$ data, suggest that the continuous degassing associated 316 to the normal activity of Stromboli ( 150 tonnes/day; Burton et al. 2009) was not clearly 317 identifiable in the OMI images. On the other hand, during the periods characterised by the 318 occurrence of summit overflows (e.g. Dec 2010 - Apr 2013; Calvari et al. 2014; Fig 4a2) as well 
319

320

321

322

323

324

325

326

327

328

329

330

331

332

333

334

335

336

337

338

339

340

341

as during the two effusive flank eruptions (e.g. Feb 2007, Aug-Oct 2014), the volcanic plume was clearly sourced by Stromboli reaching peak $\phi \mathrm{SO}_{2}$ of 480 tonnes/day (at PBL level).

Data from Batu Tara shows the first signs of low thermal activity (1-2 MW) between July and December 2006, followed by continuous activity between 2007 and 2016. From early January 2007 the thermal activity increased progressively to reach a peak of 490 MW on February 2007 (Fig. 4b1). According to 2007-2008 reports, a channelised lava flow was emplaced along the scar, reaching the sea and building a lava delta (GVP 2007). This effusive activity was accompanied by explosive activity characterised by the emission of ash-rich volcanic plumes that recurrently reached an altitude of about 3-4 km (GVP 2007). Following this, the thermal record displays a slow but gradual reduction of activity (from 100-200 MW on 2007 to about 20-30 MW on 2013).

This reduction was confirmed by field observations in 2014 , which reported the absence of lava effusion and that explosive activity was confined to the summit crater (Gaudin et al. 2017). On 23 October 2016, the thermal activity drastically decreased to less than $1 \mathrm{MW}$ suggesting the end of the eruption (Fig. 4b1).

Reports from the Darwin Volcanic Ash Advisory Centre (VAAC) throughout the whole eruption indicate the presence of a volcanic plume over Batu Tara at an altitude of 2-4 km (GVP 2008). Accordingly, in the following sections, the TRL layer is considered the most appropriate for retrieving $\phi \mathrm{SO}_{2}$ from Batu Tara (see Fig. 4b2, b4).

The first detection of $\mathrm{SO}_{2}$-rich plume over Batu Tara was on 26 July 2005 (<100 tonnes/day), about one year prior to the beginning of thermal activity in July 2006 (see blue and red lines in Fig. 4b1, b2). The $\phi \mathrm{SO}_{2}$ time-series essentially mimics the thermal trend, with both describing a short waxing phase, followed by a slow waning phase until the end of 2016 (Fig. 4b1, b2). It is 
342 interesting to note that during 2016 and during the first part of 2017, small plumes were still

343 detected over Batu Tara, despite no evidence of surface activity in the thermal data (Fig. 4b1). The

344 last $\phi \mathrm{SO}_{2}$ detection was recorded on 7 April 2017 (Fig. 4b2).

345

346 At Tinakula, the heat flux time-series defines at least three main phases of activity, interrupted by

347 year-long periods lacking thermal alerts (Fig. 4c1). During the 2000-2001 a first phase of low

348 thermal emission can be identified as characterised by sporadic and low-magnitude thermal

349 detections (<20 MW). Conversely, the relatively long-lasting phases occurring in 2006-2012

350 (eventually subdivided into distinct stages) show thermal emissions often exceeding $100 \mathrm{MW}$

351 (with a largest value of 1120 MW, 11 Feb 2006; Fig. 4c1). The 2010-2012 period was defined by

352 an increasing trend, with a maximum VRP ( 200 MW) that reached on July 2012. This recorded

353 thermal behaviour could be reconciled with a strombolian-type activity, encompassing from

354 persistent degassing to high-explosive phases, as testified by available reports (GVP 2003, 2006).

355 Between 2013 and 2017, our measurements suggest the total absence of VRP and $\phi \mathrm{SO}_{2}$ detections

356 (Fig. 4c). However, after about five years of repose, a new small (2 MW) thermal anomaly was

357 detected on 19 October 2017 (Fig. 4c1). The renewed thermal activity was immediately followed

358 by the VEI 3 explosive phase on 21 October (GVP 2017). The thermal emissions from this short

359 explosive phase were detected for a few days only, and reached a maximum VRP of $20 \mathrm{MW}$.

360

361 The $\phi \mathrm{SO}_{2}$ time-series of Tinakula between 2005 and 2017 overlap with the timing of the eruptive

362 phases depicted by the VRP data. The first clear OMI data coincides to the thermal onset on 11

363 February 2006 and is followed on 12-13 February by peak values of up to 2750 tonnes/day, using

364 the TRL level. This level appears appropriate because scientific communications report the 


75

occurrence of VEI 2 explosive eruptions reaching an altitude of less than $5 \mathrm{~km}$ (GVP 2013, Eruptive History; https://volcano.si.edu/volcano.cfm?vn=256010).

Between 2007 and 2012, there were no ash-advisory reports regarding Tinakula, suggesting a lowaltitude emission or, otherwise, an ash-free volcanic plume. According to the PBL estimates, the $\mathrm{MSO}_{2}$ measured in this period ranged from 50 to about 450 tonnes/day, showing a slight increase during 2010 and 2011. However, gas emissions declined throughout 2012, with the last OMI detection coinciding with the last thermal alert, on 21 November 2012 (Fig. 4c2). On 21-23 October 2017, the reawakening of Tinakula produced a peak $\phi \mathrm{SO}_{2}$ of $\sim 42,000$ tonnes/day, related to a $11 \mathrm{~km}$-height volcanic column from the VEI 3 explosion (NDMO Report 2017; GVP 2017).

74

\section{VRP distribution and activity regimes}

Stromboli volcano is characterised by a clear bimodal distribution of VRP values, with two groups of data separated at approximately $50 \mathrm{MW}$ (Fig. 5a). As reported in previous works (see Coppola et al. 2012, 2014), the two groups can be related to the summit explosive- and flank effusiveactivity, respectively (Fig. 5a). Actually, the ASTER images (Fig. 5a1-4) illustrate that the low radiating group (values less than about $50 \mathrm{MW}$ ) is associated to intra-crater thermal anomalies, likely related to mild-explosive activity at the summit vents. On the other hand, during sporadic detection of VRP > 100 MW associated to summit overflows (cf. Online Resource 2; 2010-2012), the thermal anomaly extended from the crater area towards the coast (Fig. 5a3).

During the effusive eruptions, the heat flux typically exceeds $100 \mathrm{MW}$, and the ASTER images reveals a flank thermal anomaly, extending along the entire length of the Sciara del Fuoco, whose origin (vent) is slightly shifted towards the NE from the crater terrace, which in turn appear cold (Fig. 5a4). The shift of this thermal anomaly clearly enhance how the effusion of lava from a lateral 
vent was able to drain the upper portion of the magmatic system feeding the typical strombolian activity at the summit crater.

391 Conversely, Batu Tara and Tinakula histograms (Fig. 5b, c) are characterised by a rough unimodal 392 distribution showing VRP modal peaks at $40 \mathrm{MW}$ and $10 \mathrm{MW}$, respectively.

393 At Batu Tara, VRP spans from $1 \mathrm{MW}$ to about $500 \mathrm{MW}$, with a arithmetic mean of $30 \mathrm{MW}$, close 394 to the modal peak shown in Fig. 5b. Notably, VRP values greater than $10 \mathrm{MW}$ are associated to 395 summit activity producing minor lava flows channelled into the scarp area, and causing an 396 extension of the observed TIR anomaly (Fig. 5b2, b3). The ASTER image of 9 December 2015, 397 acquired during a low radiant flux phase (cf. Online Resource 2), suggests that values below 10 398 MW are associated with weak thermal activity confined exclusively inside the summit vent (Fig. $3995 b 4)$.

400 The analysis of ASTER images acquired over Tinakula suggests that the VRP derived from 401 MIROVA is associated to an intra-crater thermal anomaly, sometime extending down the scarp 402 area (Fig 5c2, c3). This kind of thermal anomalies are likely associated to mild explosive activity 403 at the summit crater eventually evolving to overflows as suggested by the ASTER image acquired 404 on 11 September 2011 (Fig. 5c3). Given the lack of evidences for the occurrence of flank eruptions 405 at Tinakula, we are confident that the onset of the eruption on 11 February 2006 (with peak VRP 406 of $\sim 1120 \mathrm{MW}$ ) was related to powerful effusive eruption from summit crater, producing a lava 407 flow that reached the lower portions of the Sciara del Fuoco-like scarp. 408

409 From the analysis of VRP and ASTER images, we may infer that the bimodal distribution of VRP 410 recorded at Stromboli reflects two distinct eruptive regimes associated to (i) the typical mild- 
411 explosive summit activity and (ii) the flank effusive episodes, respectively. This bimodal

412 behaviour is not observed at Batu Tara and Tinakula volcanoes, which have not experienced lateral

413 effusion over the investigated period. Hence, the unimodal distribution of the radiative power

414 dataset seems to reflect summit activity spanning from effusive outflows to explosive ash-rich

415 activity (cf. GVP 2007, 2012).

\section{Discussion}

418 The VRP and $\phi \mathrm{SO}_{2}$ time-series presented above offer an unique opportunity to compare the 419 eruptive behaviours of the three volcanoes on a decade-long timescale. In order to homogenise the 420 two datasets we calculated the arithmetic means of VRP and $\phi \mathrm{SO}_{2}$, over monthly intervals (Fig. 421 6). Hence, we integrated over time the two monthly fluxes to obtain the cumulative Volcanic 422 Radiant Energy (cumVRE, in Joules) and the cumulative $\mathrm{SO}_{2}$ mass (cumSO $\mathrm{S}_{2}$, in tonnes) 423 throughout the whole analysed period (Fig. 7). We recognise that this procedure may be inaccurate

424 in case of extreme isolated events, such as the VEI 3 explosion of Tinakula on 21 October 2017. 425 However, for long-term analysis this methodology minimizes the effects related to poor acquisition 426 conditions (i.e. cloud coverage and geometry conditions among others; cf. Online Resource 1) and 427 allows the eruptive trends to be preserved and compared.

428 We now focus on two main aspects that reveal the different eruptive behaviour of the three 429 volcanoes: $(i)$ the long-term eruptive trends and cumulative emissions and (ii) the $\phi \mathrm{SO}_{2} / \mathrm{VRP}$ 430 ratio. 
433 As described previously, Stromboli's thermal activity is characterised by a bimodal distribution

434 (Fig. 5a), representing the "normal" strombolian activity (VRP $<50 \mathrm{MW}$ ) and the effusive activity

435 (summit overflows or flank eruptions with VRP>50 MW), respectively. These two thermal

436 regimes are also discernible in the monthly time-series (Fig. 6a1) where the persistent low level

437 thermal emission, attributed to the strombolian activity, is interrupted by peaks during effusive

438 episodes (cf. Coppola et al. 2012). On the other hand, $\phi \mathrm{SO}_{2}$ time-series (Fig. 6a2) reveals that the

439 "normal" strombolian activity ( 150 tonnes/day; Burton et al. 2009) is essentially undetected by

440 our analysis of the OMSO2 Level $2 \mathrm{G}$ images, likely because emissions are below the detection

441 limit of the sensor. The visual inspection of all OMI images and the manual selection of volcanic

442 plume sourced by Stromboli, may explain the discrepancy between our results and those obtained

443 by Carn et al. (2017), who measured, a long-term (2005-2015) average $\mathrm{SO}_{2}$ emission of $\sim 180$

444 tonnes/day. Possibly, the automatic detection method used by Carn and co-authors (2017), based

445 on pixel averaging or oversampling procedure, included data contaminated by the Etna's plume

446 which were wrongly attributed to Stromboli. Our analysis detected an $\mathrm{SO}_{2}$ plumes exclusively

447 during the two major flank eruptions of Stromboli, as well as during a few periods characterised

448 by more sustained activity and summit overflows (cf. Fig. 4a2).

449 The cumulative data indicate that during the whole analysed period (13 years), Stromboli radiated

$450 \sim 4.1 \times 10^{15} \mathrm{~J}$ of heat, and emitted a total OMI-derived $\mathrm{SO}_{2}$ mass of only $12.5 \times 10^{3}$ tonnes (Fig.

451 7a). However, over the same time window, the undetected normal activity (corresponding to about

$45295 \%$ of the days over the 13 year period) should have emitted approximately $712 \times 10^{3}$ tonnes of

$453 \mathrm{SO}_{2}$ into the atmosphere (assuming a steady flux of $\sim 150$ tonnes/day rate; Burton et al. 2009). This

454 strong imbalance illustrates the substantial contribution of the mild-strombolian explosions and 455 the passive degassing to the total degassing budget of Stromboli. Paradoxically, the cumulative 
trends (Fig. 7a) show a very good correspondence, indicating that the long-term thermal emission

457 of Stromboli is dominated by the "out of the ordinary" activity, or rather by flank eruptions and

458 summit overflows (for which we have the only $\mathrm{SO}_{2}$ detections in the OMI data).

459 The trend depicted from monthly VRP records of Batu Tara shows a rapid waxing phase followed 460 by a slow waning phase characterised by an exponential decay (Fig. 6b1). The monthly $\phi \mathrm{SO}_{2}$ trend 461 displays a similar pattern, although the waxing phase starts some months earlier, and the waning 462 trend ends some months later (Fig. 6b2). Nevertheless, the cumulative curves (Fig. 7b) show a 463 good correlation $\left(\mathrm{R}^{2}=0.9766\right)$, suggesting that activity at Batu Tara was driven by a progressive 464 decrease in the overpressure from a closed magma chamber (e.g. Machado 1974; Scandone 1979; 465 Wadge 1981; Stasiuk et al. 1993). Typically, such exponentially-decreasing trends are observed 466 during basaltic effusive eruptions (e.g. Wadge 1981, Rowland et al., 2003, Harris et al., 2000), 467 although there are exponential trends have been recorded also during he effusion of silicic lava 468 flows and domes (e.g. Mastin et al. 2008; Pallister et al., 2010; Coppola et al. 2017b). The decay 469 time constant of this type of trend is controlled by the viscosity and bulk modulus of the magma, 470 as well as by the size and geometry of the plumbing system (e.g. Wadge 1981, Rowland et al., 471 2003; Mastin et al. 2008), with large, deep magma chambers typically producing long-lasting 472 decay (Machado 1974, Scandone 1979). The longevity of the exponential trend recorded at Batu 473 Tara ( $~ 9$ years) is extraordinary, and there are no similar records of long declining trend from the 474 MODIS era (2000-2018). To our knowledge, only the 1943-1952 Paricutin eruption was 475 characterised by a similar decay constant over a total duration of nine years (Scandone 1979). 476 Notably, the previous eruption of Batu Tara (1847-1852) lasted six years, a duration quite similar 477 to the 2007-2016 eruption. As pointed out by Scandone (1979), the exponential trend also 478 indicates that after the eruption started, the magma reservoir was not fed by new magma (or that 
479 resupply was insignificant in comparison to the output rate). Our data also reveal that the $\phi \mathrm{SO}_{2}$ 480 were initially detected several months before the thermal onset of the eruption (Fig. 6b1, 6b2), thus 481 suggesting that precursory degassing activity may have preceded the arrival of magma at the 482 surface. Such a precursor would be consistent with a gas-magma decoupling during the formation 483 of the vertical magma conduit.

484

485 The eruption of Tinakula started suddenly on 11 February 2006, reaching a VRP of 1120 MW and 486 a $\phi \mathrm{SO}_{2}$ of 1562 tonnes (Fig. 4). Following this highly-energetic beginning, both VRP and $\phi \mathrm{SO}_{2}$ 487 decreased rapidly, to remain at lower levels throughout 2007 and 2008. After a pause of more than 488 one year, the thermal activity resumed in 2010, showing an escalation of VRP that culminated in 489 April-July 2012 (Fig. 6c1, c2). This thermal trend suggests a slow but progressive increase of 490 magma discharge rate during eruption, thereafter followed by a rapidly waning phase ending in 491 November 2012. According to Scandone (1996), the gradual intensification of the eruptive activity 492 is typical of explosive eruptions, although this trend has now also been recognised during basaltic 493 effusive eruptions (e.g. Reath et al. 2016; Harris et al. 2011, Coppola et al. 2017c). Scandone 494 (1996) explains the relatively slow waxing trend and rapid waning phase by a delayed bubble 495 growth within the magma chamber, which mainly depends on magma composition and depth of 496 the reservoir.

497 Notably, the rise in the 2011-2012 Tinakula thermal activity was not accompanied by an 498 equivalent increase of $\phi \mathrm{SO}_{2}$ (Fig. 6c2), suggesting a gradual modification of the gas/magma 499 balance throughout this stage. The cumulative trends highlight this feature, clearly showing a sharp 500 decoupling of CumVRE and $\mathrm{CumSO}_{2}$ after 2011 (Fig. 7c). During 2007-2010, the two cumulative 501 curves follow each other closely (suggesting a syn-eruptive degassing) but, after 2011 there is a 
502 clear mismatch between the two signals, with the rapid growth of CumVRE not being accompanied 503 by $\mathrm{CumSO}_{2}$ (Fig. 7c).

504 From November 2012 to October 2017, the absence of VRP and $\phi \mathrm{SO}_{2}$ detections suggests a 505 complete cessation of activity (cf. Fig. 4c1, 2 with Fig. 7c). This five-year long period of rest was 506 dramatically interrupted in October 2017 when the VEI 3 eruption produced $\sim 40 \times 10^{3}$ tonnes/day 507 of sulphur dioxide, the highest $\phi \mathrm{SO}_{2}$ value of the whole Tinakula dataset (Fig. 4c2).

511 the source process characteristics of $(i)$ the rate at which the magma is supplied to the level for $512 \mathrm{SO}_{2}$ exsolution $\left(\mathrm{Q}_{\text {in }}\right)$, and (ii) the rate at which the magma reaches the surface and is erupted $\left(\mathrm{Q}_{\text {out }}\right)$, 513 to release detected thermal radiation. Previous research has demonstrated how this approach 514 enables to investigate the mass partitioning during eruptive phases (endogenous versus exogenous 515 growth ) and the magma plumbing systems feeding the activity at the surface (Francis et al. 1993; 516 Harris and Stevenson, 1997; Steffke et al. 2011; Coppola et al. 2016d). In this framework, the 517 theoretical flux $\phi \mathrm{SO}_{2}$ (in tonnes/day) can be calculated by a simplified version of the petrological 518 method (Shinohara 2008),

$$
\Phi S O 2=\left(Q_{\text {in }} \cdot 2 X_{S}\right) \cdot \frac{86400}{1000}
$$

520 where $Q_{\text {in }}$ is the magma supply rate $(\mathrm{kg} / \mathrm{s})$ and $X s$ is the weight fraction of sulphur $(\mathrm{S})$ within the 521 undegassed melt.

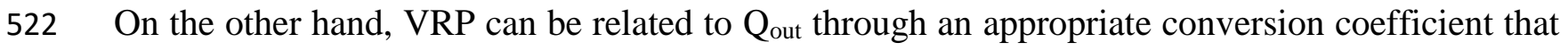
523 considers how the lava flux is accommodated by the surface extent and temperature of the active 524 lavas (Harris and Baloga 2009). For any rheological case, a single parameter called radiant density 
$525\left(c_{\mathrm{rad}}\right)$, can be used to describe the spreading and cooling properties of an active lava (Coppola et 526 al. 2013), so that

$$
V R P=\frac{Q_{\text {out }}}{\rho_{m}} \cdot c_{\text {rad }}
$$

528

529

530

where $Q_{\text {out }}$ is the magma output rate $(\mathrm{kg} / \mathrm{s}), \rho_{m}$ is the magma density $\left(\mathrm{kg} / \mathrm{m}^{3}\right)$, and $c_{\text {rad }}\left(\mathrm{J} / \mathrm{m}^{3}\right)$ is an empirical best-fit parameter that relates the lava discharge rate to the thermal radiation.

Under the condition that all the magma supplied at shallow levels is able to degas and then erupts (i.e., $Q_{\text {in }}=Q_{\text {out }}$ ), the equations 1 and 2 can be combined to give, for any volcanic system, a linear relationship between $\phi \mathrm{SO}_{2}$ and VRP, representing "balanced emissions",

$$
\Phi S O_{2}=\left(\frac{86400 \cdot \rho \cdot 2 X_{S}}{1000 \cdot c_{\text {rad }}}\right) \cdot V R P=k_{b a l} \cdot V R P
$$

where the coefficient $k_{b a l}$ defines the slope of the $\phi \mathrm{SO}_{2}$ versus VRP relationship (in tonnes day ${ }^{-}$ ${ }^{1} / \mathrm{MW}$, for simplicity). The exact value of $k_{b a l}$ depends on the chemical and physical properties of the erupted magma and may vary from case to case. Considering this variability, here we use a wide range of parameters that encompass the typical density $\left(\rho=2500 \mathrm{~kg} / \mathrm{m}^{3}\right.$; Bottinga and Weill 1972), sulphur content $\left(S=500-2500\right.$ ppm; Shinohara 2008) and radiant density $\left(c_{\text {rad }}=0.5-2 \times\right.$ $10^{8} \mathrm{~J} / \mathrm{m}^{3}$; Coppola et al. 2013) of basaltic to basaltic-andesitic magmas (as at Stromboli, Batu Tara and Tinakula).

On a $\phi \mathrm{SO}_{2}$ versus VRP plot, the resulting range of $k_{\text {bal }}$ (of 1.1 to 21.6 tonnes $\mathrm{day}^{-1} / \mathrm{MW}$ ) defines a region that corresponds to the 1:1 ratio between $Q_{\text {in }}$ and $Q_{\text {out }}$ (yellow field in Fig. 8a). Accordingly, any measurement of the $\phi \mathrm{SO}_{2} / \mathrm{VRP}$ ratio above this value, is likely to indicate “excess" $\mathrm{SO}_{2}$ degassing, that is more magma is degassed than is erupted. The opposite is true (low $\phi \mathrm{SO}_{2}$ /VRE ratio) when more magma is erupted than degassing, giving origin to a "deficit" of $\mathrm{SO}_{2}$ degassing. The standard explanation for the former case is that some of the magma is intruded and 
547 not erupted (e.g. Dzurisin 2001), and for the latter that magma that has been previously degassed

548 is involved (e.g., Steffke et al., 2011). We here term the former eruption of 'gas-rich' magma, and

549 the latter 'gas-poor'.

550 The monthly emissions derived from OMI and MODIS data are plotted in Fig. 8b, where the 551 datasets of Stromboli, Batu Tara and Tinakula define overlapping but distinct fields. For each

552 volcano, the temporal evolution of measured emission $\phi \mathrm{SO}_{2} / \mathrm{VRP}$ ratio is also showed in Fig. $6 \# 3$.

553 From this analysis, we may outline:

554 Stromboli's dataset can be divided into two sub-groups: (1) a thermally energetic group (VRP > $55510 \mathrm{MW}$ ) falling essentially within the field of gas-poor eruptions, and (2) a moderately energetic 556 group, falling within the field of balanced emissions (Fig. 8b). As previously described, OMI was 557 unable to detect the $\mathrm{SO}_{2}$ plumes sourced by the normal strombolian activity. Therefore, the 558 observed $\phi \mathrm{SO}_{2} / \mathrm{VRP}$ ratio for Stromboli, refers exclusively to the phases of lava emission 559 characterising the two major flank eruptions (highly energetic) and the episodic summit overflows 560 (moderately energetic). The two flank eruptions produce the lowest $\phi \mathrm{SO}_{2} / \mathrm{VRP}$ ratio of the time561 series (Fig. 6a3), a clear indication of the eruption of degassed (gas-poor) lava. This is consistent 562 with the reported deficit of $\mathrm{SO}_{2}$ degassing recorded during the 2007 eruption (Burton et al. 2009). 563 The gravity-driven magmastatic model proposed by Ripepe et al. (2015) provides an explanation 564 for this imbalance, whereby the flank eruptions of Stromboli essentially drain the superficial, 565 degassed magma reservoir, confined between the crater terrace and the effusive vent (e.g. Burton 566 et al. 2009; Calvari et al. 2011; Valade et al. 2016; Ripepe et al. 2017, Zakšek et al. 2015). Summit 567 overflows are characterised by moderately gas-poor to balanced $\phi \mathrm{SO}_{2} / \mathrm{VRP}$ ratio (Fig. 8b), which 568 is consistent with the fact that they represent a transient regime, separating the strombolian (gas569 rich) and the flank (gas-poor) activity (see Coppola et al. 2012). 
570 Batu Tara's dataset plot mostly within the balanced field (Fig. 8b) with only a few low-thermal-

571 energy data toward the gas-rich field. The time-series (Fig. 6b3) reveals that these low-energy,

572 gas-rich measurements correspond to the precursory phase (2005-2006), characterised by the first

573 arrival of magmatic volatiles at the surface. During and after the onset of the eruption, the

$574 \phi \mathrm{SO}_{2} / \mathrm{VRP}$ ratio does not show any significant long-term pattern (Fig. 6b3), indicating the absence

575 of gas accumulation/separation and an overall syn-eruptive degassing (Parfitt and Wilson, 1995).

576 This behaviour, together with the coherent exponential trends (Fig. 7b), suggests that the Batu Tara

577 eruption tapped a pressurised magma chamber (Wadge 1981) located below the $\mathrm{SO}_{2}$ exsolution

578 level, and that magma ascent was sufficiently fast to limit the separation of the gas phase along the

579 central conduit (Parfitt and Wilson 1995).

580 Tinakula's dataset exhibit the largest variability of the $\phi \mathrm{SO}_{2} / \mathrm{VRP}$ ratio and contains the highest

581 value (of $\sim 10,000$ Tonnes day-1/MW recorded during the VEI 3 eruption, October 2017) as well

582 as some data falling in the moderately gas-poor region (Fig. 8b). The extreme ratio of October

5832017 (Fig. 6c3) suggests that this event was possibly preceded by a period of gas accumulation at

584 depth. Interestingly, between 2006-2012, the gas/thermal ratio gradually declined, evolving from

585 moderately gas-rich (2006-2007) to gas-poor conditions (2011-2012; Fig. 6c3). This terminal gas-

586 depleted stage corresponds to the progressive intensification of thermal emission (Fig. 6c3), likely

587 resulting from an increase in magma discharge rate. According to Scandone (1996), this style of

588 evolution may be promoted by a volatile-saturated magma confined within a rigid magma

589 chamber. In this way, the escalation of observed discharge rate can be driven by an increase in the

590 rate of vesiculation by the progressive emptying of the reservoir enhancing magma decompression

591 during the eruptions. Consequently, high discharge rates favour the tapping of increasingly deeper

592 levels in a zoned reservoir with possible eruption of magma with a lower gas content (Spera, 1984; 
Blake and Ivey 1986). This seems to be exactly the case for Tinakula, where the slow eruption of

594 a gas-rich magma stored at the top of the reservoir (2006-2007 phase), possibly unloaded the 595 residual degassed magma, stored at lower levels and erupted during the last stage of activity (20115962012 phase).

597

\section{Conclusions}

599 Batu Tara and Tinakula are two poorly known volcanoes displaying morphologies and short-term 600 activity very similar to Stromboli. However, our analysis of satellite data reveals that over 601 timescales of several years, the three volcanoes display quite different eruptive behaviours in terms 602 of ( $i$ ) persistence and magnitude of thermal and degassing fluxes (VRP and $\phi \mathrm{SO}_{2}$, respectively), 603 (ii) long-term eruptive trends and (iii) $\phi \mathrm{SO}_{2} / \mathrm{VRP}$ ratios. These contrasting behaviours are likely 604 attributable to differences in the associated magmatic systems. The efficient, well-developed 605 plumbing system of Stromboli allows the magma column to reach very shallow depths (just below 606 the crater terrace) and persistently degas. These results in the continuous detection of low thermal 607 anomalies, and the continuous emission of gas, albeit at levels undetectable by the OMI sensor. 608 However, flank eruptions are able to drain the top of the magmatic column, with the consequent 609 effusion of degassed magma. Conversely, the eruptive trends recorded at Batu Tara are indicative 610 of a less-well developed magmatic system, lacking a persistently-fed shallow conduit, and

611 suggesting the involvement of a deep magma chamber (below the $\mathrm{SO}_{2}$ exsolution level), possibly 612 erupting every hundred years. Finally, the behaviour of Tinakula may be explained by intermittent 613 eruptions (every few years) from a volatile-zoned magma chamber, possibly located at 614 intermediate depths (i.e. around the $\mathrm{SO}_{2}$ exsolution level). Notably, the last five years of activity 
615 at Tinakula indicates a closed system behaviour, with a possible gas accumulation that was erupted

616 during the VEI 3 explosive event of October 2017.

617 Our results outline the potential of comparative analysis of long-term eruptive trends. The satellite

618 data with their continuous, long-lasting, global coverage represent an invaluable resource that can

619 inform on eruption processes at unmonitored volcanoes. The combined analysis of VRP and $\phi \mathrm{SO}_{2}$

620 constitutes a promising and powerful tool to decrypt major changes in the eruptive behaviour of

621 any active volcano, thus adding a fundamental contribution for the evaluation of evolving volcanic

622 hazards.

\section{References}


644 Aiuppa A, de Moor JM, Arellano S, Coppola D, Francofonte V, Galle B, Giudice G, Liuzzo M, 645 Mendoza E, Saballos A, Tamburello G, Battaglia A, Bitetto M, Gurrieri S, Laiolo M, Mastrolia A, 646 Moretti M (2018) Tracking formation of a lava lake from ground and space: Masaya volcano 647 (Nicaragua), 2014-2017. Geochem Geophys Geosyst $19 \quad$ (2): 496-515. 648 https://doi.org/10.1002/2017GC007227

649

650 Allard P, Carbonnelle J, Métrich N, Loyer H, Zettwoog P (1994) Sulphur output and magma 651 degassing budget of Stromboli volcano. Nature 368: 326-330. doi:10.1038/368326a0

652

653 Allard P, Aiuppa A, Burton M, Caltabiano T, Federico C, Salerno G, La Spina A (2008) Crater 654 gas emissions and the magma feeding system of Stromboli volcano. In: Calvari S, Inguaggiato S, 655 Puglisi G, Ripepe M, Rosi M (ed), Learning from Stromboli, AGU Geophysics Monograph Series, 656 182, Washington DC, pp. 65-80. doi: 10.1029/182GM07

657

658 Andres RJ, Kasgnoc AD (1998) A time-averaged inventory of subaerial volcanic sulfur emissions.

$659 \quad$ J Geophys Res 103 (D19): 25251-25261.

660

661 Barberi F, Rosi M, Sodi A (1993) Volcanic hazard assessment at Stromboli based on review of 662 historical data. Acta Vulcanol 3:173-187.

663

664 Barrière J, Oth A, Theys N, d'Oreye N, Kervyn F (2017) Long-term monitoring of long-period 665 seismicity and space-based SO2 observations at African lava lake volcanoes Nyiragongo and 
666 Nyamulagira (DR Congo). Geophys Res Lett 44(12): 6020-6029. 667 http://dx.doi.org/doi:10.14470/XI058335

668

669 Beirle S, Hormann C, Penning de Vries M, Dorner S, Kern C, Wagner T (2014) Estimating the 670 volcanic emission rate and atmospheric lifetime of $\mathrm{SO}_{2}$ from space: a case study for K1lauea 671 volcano, Hawai'i. Atmos Chem Phys 14: 8309-8322. https://doi.org/10.5194/acp-14-8309-2014 672

673 Biggs J, Ebmeier SK, Aspinall WP, Lu Z, Pritchard ME, Sparks RSJ, Mather TA (2014) Global 674 link between deformation and volcanic eruption quantified by satellite imagery. Nat Commun 5: 675 3471. doi: 10.1038/ncomms4471

676

677 Biggs J, Pritchard ME (2017) Global volcano monitoring: What does it mean when volcanoes 678 deform? Elements 13(1): 17-22. https://doi.org/10.2113/gselements.13.1.17

679

680 Blake S, Ivey GN (1986) Density and viscosity gradients in zoned magma chambers, and their 681 influence on withdrawal dynamics. J Volcanol Geotherm Res 30: 201-230. 682 https://doi.org/10.1016/0377-0273(86)90055-7

683

684 Bottinga Y, Weill DF (1972) The viscosity of magmatic silicate liquids; a model calculation. Am 685 J Sci: 272 (5): 438-475. https://doi.org/10.1016/0377-0273(86)90055-7 
687 Burton MR, Caltabiano T, Murè F, Salerno GG, Randazzo D (2009) $\mathrm{SO}_{2}$ flux from Stromboli 688 during the 2007 eruption: results from the FLAME network and traverse measurements. J Volcanol 689 Geotherm Res 182 (3-4): 214-220. https://doi.org/10.1016/j.jvolgeores.2008.11.025

690

691 Calvari S, Spampinato L, Bonaccorso A, Oppenheimer C, Rivalta E, Boschi E (2011). Lava 692 effusion - A slow fuse for paroxysms at Stromboli volcano? Earth Planet Sci Lett 301 (1-2): 317693 323. https://doi.org/10.1016/j.eps1.2010.11.015

694

695 Calvari S, Bonaccorso A, Madonia P, Neri M, Liuzzo M, Salerno GG, Behncke B, Caltabiano T, 696 Cristaldi A, Giuffrida G, La Spina A, Marotta E, Ricci T, Spampinato L (2014) Major eruptive 697 style changes induced by structural modifications of a shallow conduit system: the 2007-2012 698 Stromboli case. Bull Volcanol 76: 841. https://doi.org/10.1007/s00445-014-0841-7

699

700 Carn SA, Clarisse L, Prata AJ (2016) Multi-decadal satellite measurements of global volcanic 701 degassing. J Volcanol Geotherm $\quad$ Res $\quad 311: \quad 99-134$. 702 https://doi.org/10.1016/j.jvolgeores.2016.01.002

703

704 Carn SA, Fioletov VE, McLinden CA, Li C, Krotkov NA (2017) A decade of global volcanic $\mathrm{SO}_{2}$ 705 emissions measured from space. Sci Rep 7: 44095. doi:10.1038/srep44095 706

707 Chaussard E, Amelung F, Aoki Y (2013) Characterization of open and closed volcanic systems in 708 Indonesia and Mexico using InSAR time series. J Geophys Res SE 118: 3957-3969. 709 https://doi.org/10.1002/jgrb.50288 
711 Cook HJ, Koraua BL, McConachy TF (2012) Observations of Tinakula Volcano, 10 May 2012,

712 Solomon Islands $\left(-10.38^{\circ} \mathrm{S} / 165.8^{\circ} \mathrm{E}\right)$, Informal report, $12 \mathrm{pp}$.

713

714 Coppola D, Cigolini C (2013) Thermal regimes and effusive trends at Nyamuragira volcano (DRC)

715 from MODIS infrared data. Bull Volcanol 75 (8): 1-15. https://doi.org/10.1007/s00445-013-0744-

$716 \underline{Z}$

717

718 Coppola D, Piscopo D, Laiolo M, Cigolini C, Delle Donne D, Ripepe M (2012) Radiative heat

719 power at Stromboli volcano during 2000-2011: Twelve years of MODIS observations. J Volcanol

720 Geotherm Res 215-216: 48-60. https://doi.org/10.1016/j.jvolgeores.2011.12.001

721

722 Coppola D, Laiolo M, Piscopo D, Cigolini C (2013) Rheological control on the radiant density of 723 active lava flows and domes. J Volcanol Geotherm Res 249: 39-48.

724 https://doi.org/10.1016/j.jvolgeores.2012.09.005

725

726 Coppola D, Laiolo M, Delle Donne D, Ripepe M, Cigolini C (2014) Hot-spot detection and

727 characterization of strombolian activity from MODIS infrared data. Int J Remote Sens 35 (9):

728 3403-3426. https://doi.org/10.1080/01431161.2014.903354

729

730 Coppola D, Macedo O, Ramos D, Finizola A, Delle Donne D, del Carpio J, White R, McCausland

731 W, Centeno R, Rivera M, Apaza F, Ccallata B, Chilo W, Cigolini C, Laiolo M, Lazarte I, Machaca

732 R, Masias P, Ortega M, Puma N, Taipe E (2015) Magma extrusion during the Ubinas 2013-2014 
733 eruptive crisis based on satellite thermal imaging (MIROVA) and ground-based monitoring. J

734 Volcanol Geotherm Res 302: 199-210. https://doi.org/10.1016/j.jvolgeores.2015.07.005

735

736 Coppola D, Laiolo M, Cigolini C (2016a) Fifteen years of thermal activity at Vanuatu's volcanoes

737 (2000-2015) revealed by MIROVA. J Volcanol Geotherm Res 322: 6-19.

738 https://doi.org/10.1016/j.jvolgeores.2015.11.005

739

740 Coppola D, Laiolo M, Lara L, Cigolini C, Orozco G (2016b) The 2008 "silent" eruption of 741 Nevados de Chillán (Chile) detected from space: Effusive rates and trends from the MIROVA 742 system. J Volcanol Geotherm Res 327: 322-329. doi:10.1016/j.jvolgeores.2016.08.016

743

744 Coppola D, Laiolo M, Cigolini C, Delle Donne D, Ripepe M (2016c) Enhanced volcanic hot-spot 745 detection using MODIS IR data: results from the MIROVA system. In: Harris AJL, De Groeve T, 746 Garel F, Carn SA (ed), Detecting, Modelling, and Responding to Effusive Eruptions, Geological 747 Society, London, Special Publication 426. https://doi.org/10.1144/SP426.5

748

749

Coppola D, Campion R, Laiolo M, Cuoco E, Balagizi C, Ripepe M, Cigolini C, Tedesco D (2016d)

750 Birth of a lava lake: Nyamulagira volcano 2011-2015. Bull Volcanol 78. doi:10.1007/s00445-016$751 \quad 1014-7$

752

753 Coppola D, Ripepe M, Laiolo M, Cigolini C (2017a) Modelling satellite-derived magma discharge 754 to explain caldera collapse. Geology 45 (6): 523-526: https://doi.org/10.1130/G38866.1 
756 Coppola D, Laiolo M, Franchi A, Massimetti F, Cigolini C, Lara LE (2017b) Measuring effusion 757 rates of obsidian lava flows by means of satellite thermal data. J Volcanol Geotherm Res 347, 8290. https://doi.org/10.1016/j.jvolgeores.2017.09.003

759

760

Coppola D, Di Muro A, Peltier A, Villeneuve N, Ferrazzini V, Favalli M, Bachèlery P, Gurioli L,

761 Harris AJL, Moune S, Vlastélic I, Galle B, Arellano S, Aiuppa A (2017c) Shallow system 762 rejuvenation and magma discharge trends at Piton de la Fournaise volcano (La Réunion Island).

763 Earth Planet Sci Lett 463: 13-24. https://doi.org/10.1016/j.eps1.2017.01.024

764

765

Davies HL, Keene JB, Hashimoto K, Joshima M, Stuart JE, Tiffin DL (1986) Bathymetry and

766 Canyons of the western Solomon Sea. Geo-Marine Lett 6 (4): 181-191.

767 https://doi.org/10.1007/BF02239579

768

769

Davies HL, Bani P, Black P, Smith I, Garaebiti E (2005) Geology of Oceania (including Fiji, Ping

770 and Solomons). In: Selley RC, Cocks LRM, Plimer IR (ed), Encyclopedia of Geology, Oxford

771 Elsevier, 4, pp. 109-123.

772

773 De Astis G, Ventura G, Vilardo G (2003) Geodynamic significance of the Aeolian volcanism 774 (Southern Tyrrhenian Sea, Italy) in light of structural, seismological, and geochemical data. 775 Tectonics 22(4):1040. https://doi.org/10.1029/2003TC001506

776

777 Dean KG, Servilla M, Roach A, Foster B, Engle K (1998) Satellite monitoring of remote volcanoes 778 improves study efforts in Alaska. EOS, Transactions of the American Geophysical Union 79: 422779 423. https://doi.org/10.1029/98EO00316 
Dzurisin D (2001) A comprehensive approach to monitoring volcano deformation as a window on

782 the eruption cycle. Rev Geophys 41 (1). https://doi.org/10.1029/2001RG000107

783

784 Ebmeier SK, Andrews BJ, Araya MC, Arnold DWD, Biggs J, Cooper C, Cottrell E, Furtney M, 785 Hickey J, Jay J, Lloyd R, Parker AL, Pritchard ME, Robertson E, Venzke E, Williamson JL (2016) 786 Synthesis of global satellite observations of magmatic and volcanic deformation: implications for 787 volcano monitoring \& the lateral extent of magmatic domains. J Appl Volcanol 7:2. 788 https://doi.org/10.1186/s13617-018-0071-3

789

790

Elburg MA, Van Bergen MJ, Foden JD (2004) Subducted upper and lower continental crust 791 contributes to magmatism in the collision sector of the Sunda-Banda arc, Indonesia. Geology 32:

792 41-44. doi: 10.1130/G19941.1

793

794 Elburg MA, Kamenetsky VS, Foden JD, Sobolev A (2007) The origin of medium-K ankaramitic 795 arc magmas from Lombok (Sunda act, Indonesia): Mineral and melt inclusion evidence. Chem 796 Geol 240: 260-279. doi: 10 1016/j chemgeo 200702015.

797

798 Favalli MM, Karátson D, Mazzuoli R, Pareschi MT, Ventura G (2005) Volcanic geomorphology 799 and tectonics of the Aeolian archipelago (Southern Italy) based on integrated DEM data. Bull 800 Volcanol 68: 157-170. https://doi.org/10.1007/s00445-005-0429-3

801 
802 Fioletov VE, McLinden CA, Krotkov N, Li C (2015) Lifetimes and emissions of SO2 from point 803 sources estimated from OMI. Geophys Res Lett 42, 1969-1976. 804 https://doi.org/10.1002/2015GL063148

805

806 Fioletov VE, McLinden CA, Krotkov N, Li C, Joiner J, Theys N, Carn N, Moran M (2016) A 807 global catalogue of large SO2 sources and emissions derived from the Ozone Monitoring 808 Instrument. Atmos Chem Phys 16: 11497-11519. doi:10.5194/acp-16-11497-2016.

809

810 Flower VJB, Oommen T, Carn SA (2016) Improving global detection of volcanic eruptions using

811 the Ozone Monitoring Instrument (OMI). Atmos Meas Tech 9: 5487-5498. Doi:10 5194/amt-9-

812 5487-2016. https://doi.org/10.5194/amt-9-5487-2016

813

814 Francalanci L, Tommasini S, Conticelli S, Davies GR (1999) Sr isotope evidence for short magma 815 residence time for the $20^{\text {th }}$ century activity at Stromboli volcano, Italy. Earth Planet Sci Lett 167 816 (1-2): 61-69. https://doi.org/10.1016/S0012-821X(99)00013-8

817

818 Francis P, Oppenheimer C, Stevenson D (1993) Endogenous growth of persistently active 819 volcanoes. Nature 366: 554-557. doi:10.1038/366554a0

820

821 Ganci G, Vicari A, Cappello A, Del Negro C (2012) An emergent strategy for volcano hazard 822 assessment: from thermal satellite monitoring to lava flow. Remote Sens Environ 119:197-207. 823 http://doi.org/10.1016/j.rse.2011.12.021 
825 Gaudin D, Taddeucci J, Scarlato P, del Bello E, Ricci T, Orr T, Houghton B, Harris A, Rao S, 826 Bucci A (2017) Integrating puffing and explosions in a general scheme for Strombolian-style 827 activity. J Geophys Res Solid Earth 122. https://doi.org/10.1002/2016JB013707

828

829 Global Volcanism Program (1971) Report on Tinakula (Solomon Islands). CSLP 1301, 87-71. D. 830 Dawea-taukalo, Sub Station, Graciosa Bay, Santa Cruz, B.S.I.P.; R.B. Thompson, Geological 831 Survey Dept., Honiara, $\quad$ Guadalcanal, $\quad$ B.S.I.P.

832 https://volcano.si.edu/volcano.cfm?vn=256010\#bgvn_197110

833

834 Global Volcanism Program (2003) Report on Tinakula (Solomon Islands). In: Venzke, E (ed.), 835 Bulletin of the Global Volcanism Network, 28:1. Smithsonian Institution. 836 http://dx.doi.org/10.5479/si.GVP.BGVN200301-256010

837

838 Global Volcanism Program (2006) Report on Tinakula (Solomon Islands). In: Wunderman, R 839 (ed.), Bulletin of the Global Volcanism Network, 31:3. Smithsonian Institution. 840 http://dx.doi.org/10.5479/si.GVP.BGVN200603-256010

841

842 Global Volcanism Program (2007) Report on Batu Tara (Indonesia). In: Wunderman, R (ed.), 843 Bulletin of the Global Volcanism Network, 32:12. Smithsonian Institution. 844 http://dx.doi.org/10.5479/si.GVP.BGVN200712-264260

845

846 Global Volcanism Program (2008) Report on Batu Tara (Indonesia). In: Wunderman, R (ed.), 847 Bulletin of the Global Volcanism Network, 33:7. Smithsonian Institution. 848 https://dx.doi.org/10.5479/si.GVP.BGVN200807-264260 
850 Global Volcanism Program (2011) Report on Batu Tara (Indonesia). In: Wunderman, R (ed.), 851 Bulletin of the Global Volcanism Network, 36:10. Smithsonian Institution. 852 http://dx.doi.org/10.5479/si.GVP.BGVN201110-264260

853

854 Global Volcanism Program (2012) Report on Tinakula (Solomon Islands). In: Wunderman, R 855 (ed.), Bulletin of the Global Volcanism Network, 37:6. Smithsonian Institution. 856 https://dx.doi.org/10.5479/si.GVP.BGVN201206-256010

857

858 Global Volcanism Program (2013) Volcanoes of the World, v. 4.6.6. Venzke, E (ed.). Smithsonian 859 Institution. Downloaded 14 Mar 2018. https://dx.doi.org/10.5479/si.GVP.VOTW4-2013

860

861 Global Volcanism Program (2014) Report on Batu Tara (Indonesia). In: Wunderman, R (ed.), 862 Bulletin of the Global Volcanism Network, 39:1. Smithsonian Institution. 863 http://dx.doi.org/10.5479/si.GVP.BGVN201401-264260

864

865 Global Volcanism Program (2016) Report on Batu Tara (Indonesia). In: Venzke, E (ed.), Bulletin 866 of the Global Volcanism Network, 41:11. Smithsonian Institution.

867

868 Global Volcanism Program (2017) Report on Tinakula (Solomon Islands). In: Sennert, S K (ed.), 869 Weekly Volcanic Activity Report, 18 October-24 October 2017. Smithsonian Institution and US 870 Geological Survey.

871 
872 Harris AJL (2013) Thermal Remote Sensing of Active Volcanoes. A User's Manual Cambridge

873 University Press, pp. 736. https://doi.org/10.1017/CBO9781139029346

874

875 Harris AJL, Stevenson D (1997) Magma budgets and steady-state activity of Vulcano and 876 Stromboli. Geophys Res Lett 24(9): 1043-1046. https://doi.org/10.1029/97GL00861

877

878 Harris AJL, Baloga SM (2009) Lava discharge rates from satellite-measured heat flux. Geophys

879 Res Lett 36, L19302. https://doi.org/10.1029/2009GL039717

880

881 Harris AJL, Murray JB, Aries SE, Davies MA, Flynn LP, Wooster MJ, Wright R, Rothery D 882 (2000) Effusion rate trends at Etna and Krafla and their implications for eruptive mechanisms. J 883 Volcanol Geotherm Res 102: 237-270.

884

885 Harris AJL, Flynn LP, Keszthelyi L, Mouginis-Mark PJ, Rowland SK, Resing JA (1998)

886 Calculation of lava effusion rates from Landsat TM data. Bull Volcanol 60:52-71.

887

888 Harris AJL, Dehn J, Calvari S (2007) Lava effusion rate definition and measurement: A review.

889 Bull Volcanol 70(1): 1-22. https://doi.org/10.1007/s00445-007-0120-y

890

891 Harris AJL, Steffke A, Calvari S, Spampinato L (2011) Thirty years of satellite-derived lava 892 discharge rates at Etna: implications for steady volumetric output. J Geophys Res 116: B08204. 893 http://dx.doi.org/10.1029/2011JB008237. 
895 Harris AJL, Villeneuve N, Di Muro A, Ferrazzini V, Peltier A, Coppola D, Favalli M, Bachèlery

896 P, Froger JL, Gurioli L, Moune S, Vlastélic I, Galle B, Arellano S (2017) Effusive crises at Piton 897 de la Fournaise 2014-2015: a review of a multi-national response model. J Appl Volcanol 6 (11):

898 https://doi.org/10.1186/s13617-017-0062-9

899

900 Hayer CS, Wadge G, Edmonds M, Christopher T (2016) Sensitivity of OMI SO2 measurements 901 to variable eruptive behaviour at Soufrière Hills Volcano, Montserrat. J Volcanol Geotherm Res 902 312:1-10. https://doi.org/10.1016/j.jvolgeores.2016.01.014

903

904 Jarvis A, Reuter HI, Nelson A, Guevara E (2008) Hole-filled seamless SRTM data V4, 905 International Centre for Tropical Agriculture (CIAT), available from http://srtm.csi.cgiar.org.

906

907 Koeppen WC; Pilger E, Wright R (2011) Time series analysis of infrared satellite data for detecting 908 thermal anomalies: a hybrid approach. Bull Volcanol 73 (5): 577-593. doi:10.1007/s00445-010$909 \quad 0427-y$

910

911 Krotkov NA, Li C, Leonard P (2014) OMI/Aura Sulphur Dioxide (SO2) Total Column Daily L2

912 Global Gridded 0.125 degree x 0.125 degree V3. Greenbelt, MD, USA, Goddard Earth Sciences

913 Data and Information Services Center (GES DISC): Accessed [01032018-10032018] 914 10.5067/Aura/OMI/DATA2023.

915 
Krueger AJ, Walter LS, Bhartia PK, Schnetzler CC, Krotkov NA, Sprod I, Bluth GJS (1995) Volcanic sulfur dioxide measurements from the total ozone mapping spectrometer instruments. J Geophys Res 100(D7):14057-14056. https://doi.org/10.1029/95JD01222

Landi P, Corsaro RA, Francalanci L, Civetta L, Miraglia L, Pompilio M, Tesoro R (2009) Magma during the 2007 Stromboli eruption (Aeolian Islands, Italy): mineralogical, geochemical and isotopic data. J Volcanol Geotherm Res 182 (3-4): 255-268.

Li C, Krotkov NA, Carn SA, Zhang Y, Spurr RJD, Joiner J (2017). New-generation NASA Aura Ozone Monitoring Instrument volcanic $\mathrm{SO}_{2}$ dataset: Algorithm description, initial results, and continuation with the Suomi-NPP Ozone Mapping and Profiler Suite. Atmos. Meas. Tech. 10: 445-458. doi:10.5194/amt-10-445-2017

Machado F (1974) The search for magmatic reservoirs. In: Civetta L, Gasparini P, Luongo G, Rapolla A (ed), Physical Volcanology, Elsevier, Amsterdam, pp.255-273.

Marani MP, Gamberi F, Rosi M, Bertagnini A, Di Roberto A (2009) Subaqueous density flow processes and deposits of an island volcano landslide (Stromboli Island, Italy). Sedimentology 56: 1488-1504. https://doi.org/10.1111/j.1365-3091.2008.01043.x

Mastin LG, Lisowski M, Roeloffs E, Beeler N (2008) Improved constraints on the estimated size and volatile content of the Mount St. Helens magma system from the 2004-2008 history of dome growth and deformation. Geophis Res Lett 36: L20304. https://doi.org/10.1029/2009GL039863 
940 McCormick-Kilbride B, Edmonds M, Biggs J, (2016) Observing eruptions of gas-rich, 941 compressible magmas from space. Nat Comm 7: 13744. Doi:10.1038/ncomms13744

942

943 Métrich N. Bertagnini A, Di Muro A (2009) Conditions of magma storage, degassing and ascent 944 at Stromboli: New insights into the volcano plumbing system with inferences on the eruptive 945 dynamics. J Petrol 51 (3): 603-626. doi: 10.1093/petrology/egp083.

946

947 Murphy SW, Wright R, Oppenheimer C, Filho CRS (2013) MODIS and ASTER synergy for 948 characterizing thermal volcanic activity. Remote Sens Environ 131:195-205. $949 \quad$ http://dx.doi.org/10.1016/j.rse.2012.12.005

950

951 NDMO Report 2017 National Disaster Management Office, Solomon Islands, Report No. 2 952 Tinakula Volcano, 2017.10.26. http://www.ndmo.gov.sb/index.php/situation-report/197-national953 situation-report-02-tinakula-volcano

954

955 Newhall CG, Self S (1982) The volcanic explosivity index (VEI): an estimate of explosive 956 magnitude for historical volcanism. J Geophys Res 87 (C2): 1231-1238.

957

958 Oppenheimer C, McGonigle AJS, Allard P, Wooster MJ, Tsanev V (2004) Sulfur, heat, and 959 magma budget of Erta 'Ale lava lake, Ethiopia. Geology 32 (6): 509-512. doi: 10.1130/G20281.1 960 
961 Parfitt EA, Wilson L, (1995) Explosive volcanic eruptions-IX. The transition between Hawaiian962 style lava fountaining and Strombolian explosive activity. Geophys J Int 121(1): $226-232$. 963 https://doi.org/10.1111/j.1365-246X.1995.tb03523.x

964

965 Pieri D, Abrams M (2004) ASTER watches the world's volcanoes: a new paradigm for 966 volcanological observations from orbit. J Volcanol Geotherm Res 135: 13-28. 967 https://doi.org/10.1016/j.jvolgeores.2003.12.018

968

969 Pistolesi M, Delle Donne D, Pioli L, Rosi M, Ripepe M (2011) The 15 March 2007 explosive crisis 970 at Stromboli volcano, Italy: assessing physical parameters through a multidisciplinary approach. J

971 Geophys Res, 116, B12206. https://doi.org/10.1029/2011JB008527

972

973 Pyle DM, Mather TA, Biggs J (2013) Remote sensing of volcanoes and volcanic processes: 974 integrating observation and modelling - introduction. In: Pyle, D. M., Mather, T. A. \& Biggs, J. 975 (ed), Remote Sensing of Volcanoes and Volcanic Processes: Integrating Observation and 976 Modelling. Geological Society, London, Sp Pub 380, pp. 1-13. doi: 977 https://doi.org/10.1144/SP380.14

978

979 Ramsey MS (2016) Synergistic use of satellite thermal detection and science: a decadal perspective 980 using ASTER. In: Harris AJL, De Groeve T, Garel F, Carn SA (ed), Detecting, Modelling, and 981 Responding to Effusive Eruptions, Geological Society, London, Sp Pub 426: 115-136. 982 https://doi.org/10.1144/SP426.23 
984 Ramsey MS, Harris AJL (2013) Volcanology 2020: how will thermal remote sensing of volcanic 985 surface activity evolve over the next decade? J Volcanol Geotherm Res 249: 217-233. 986 https://doi.org/10.1016/j.jvolgeores.2012.05.011

987

988 Reath KA, Ramsey MS, Dehn J, Webley PW (2016) Predicting eruptions from precursory activity 989 using remote sensing data hybridization. J Volcanol Geotherm Res 321: 18-30. 990 https://doi.org/10.1016/j.jvolgeores.2016.04.027

991

992 Ripepe M, Delle Donne D, Harris A, Marchetti E, Ulivieri G (2008) Dynamics of Stromboli 993 activity. In: Calvari S, Inguaggiato S, Puglisi G, Ripepe M, Rosi M (ed), Learning from Stromboli: 994 AGU Geophysics Monograph Series, 182, Washington DC, pp. 39-48.

995

996 Ripepe M, Delle Donne D, Genco R, Maggio G, Pistolesi M, Marchetti E, Lacanna G, Ulivieri G, 997 Poggi P (2015) Volcano seismicity and ground deformation unveil the gravity-driven magma 998 discharge dynamics of a volcanic eruption. Nature Commun 6: 6998. doi:10 1038/ncomms7998. 999

1000 Ripepe M, Pistolesi M, Coppola D, Delle Donne D, Genco R, Lacanna G, Laiolo M, Marchetti E, 1001 Ulivieri G, Valade S (2017) Forecasting Effusive Dynamics and decompression rates by 1002 magmastatic model at Open-vent Volcanoes. Sci Rep 7: 3885. 10.1038/s41598-017-03833-3

1004 Rosi M, Bertagnini A, Landi P (2000) Onset of persisting activity at Stromboli Volcano (Italy). 1005 Bull Volcanol 62: 294-300. https://doi.org/10.1007/s004450000098 
1007 Rosi M, Pistolesi M, Bertagnini A, Landi P, Pompilio M, Di Roberto A (2013) Stromboli volcano, 1008 Aeolian Islands (Italy): present eruptive activity and hazards. In: Lucchi F, Peccerillo A, Keller J, 1009 Tranne CA, Rossi PL (ed) The Aeolian Islands Volcanoes, Geological Society London Memoirs 1010 37(1), chapter 14, The Geological Society of London, pp.473-490. https://doi org/10 1144/M37

1011 14. https://doi.org/10.1144/M37.14

1012

1013 Rothery D, Coppola D, Saunders C (2005) Analysis of volcanic activity patterns using MODIS 1014 thermal alerts. Bull Volcanol 67 (6): 539-556. https://doi.org/10.1007/s00445-004-0393-3

1015

1016 Scandone R (1979) Effusion rate and energy balance of Paricutín eruption (1943-1952), 1017 Michoacán, Mexico. J Volcanol Geotherm Res 6: 49-59.

1018

1019 Rowland SK, Harris AJL, Wooster MJ, Garbeil H, Mouginis-Mark PJ, Amelung F, Wilson L 1020 (2003) Volumetric characteristics of lava flows from interferometric radar and multispectral 1021 satellite data: the 1995 Fernandina and 1998 Cerro Azul eruptions in the western Galápagos. Bull 1022 Volcanol 65:311-330.

1023

1024 Scandone R (1996) Factors controlling the temporal evolution of explosive eruptions. J Volcanol 1025 Geotherm Res 72 (1-2): 71-83. https://doi.org/10.1016/0377-0273(95)00086-0

1026

1027 Schuth S, Münker C, König S, Qopoto C, Basi S, Garbe-Schönberg D, Ballhaus C (2009) 1028 Petrogenesis of Lavas along the Solomon Island Arc, SW Pacific: Coupling of Compositional 1029 Variations and Subduction Zone Geometry. J Petrol 50 (5): 781-811. 1030 https://doi.org/10.1093/petrology/egp019 
1032 Shinohara H (2008) Excess degassing from volcanoes and its role on eruptive and intrusive 1033 activity. Review of Geophysics 46(4): RG4005. https://doi.org/10.1029/2007RG000244

1034

1035 Spera F (1984) Some numerical experiments on the withdrawal of magma from crustal reservoirs. 1036 J Geophys Res 89: 8222-8236.

1037

1038 Stasiuk MV, Jaupart C, Sparks RSJ (1993) Influence of cooling on lava-flow dynamics. Geology $1039 \quad 21: 335-338$

1040

1041

1042

1043 1044

1045 1046

1047 1048 1049 1050 1051

1052 $1053 \quad \underline{016-1072-X}$ 
1055 Van Bergen MJ, Vroon PZ, Varekamp JC, Poorter RPE (1992) The origin of the potassic rock 1056 suite from Batu Tara volcano (East Sunda Arc, Indonesia). Lithos 28 (3-6): 261-282. 1057 https://doi.org/10.1016/0024-4937(92)90010-V

1058

1059 Vaughan RG, Keszthelyi LP, Lowenstern JB, Jaworowski C, Heasler H (2012) Use of ASTER 1060 and MODIS thermal infrared data to quantify heat flow and hydrothermal change at Yellowstone 1061 National Park. J Volcanol Geotherm Res 233-234: 72-89. 1062 https://doi.org/10.1016/j.jvolgeores.2012.04.022.

1063

1064 Ventura G (2013) Kinematics of the Aeolian volcanism (Southern Tyrrhenian sea) from 1065 geophysical and geological data. In: Lucchi F, Peccerillo A, Keller J, Tranne CA, Rossi PL (eds.) 1066 The Aeolian Islands Volcanoes, Geological Society London Memoirs 37(1), chapter 2, The 1067 Geological Society of London, pp.3-11. https://doi.org/10.1144/M37.2

1068

1069 Wadge G (1981) The variation of magma discharge during basaltic eruptions. J Volcanol 1070 Geotherm Res 11(2-4): 139-168. https://doi.org/10.1016/0377-0273(81)90020-2

1072 Wooster MJ, Zhukov B, Oertel D (2003) Fire radiative energy for quantitative study of biomass 1073 burning: derivation from the BIRD experimental satellite and comparison to MODIS fire products. 1074 Remote Sens Environ 86: 83-107. https://doi.org/10.1016/S0034-4257(03)00070-1 
1076 Wright R, Carn SA, Flynn LP (2005) A satellite chronology of the May-June 2003 eruption of 1077 Anatahan volcano.J Volcanol Geotherm Res 146(1-3), 102-116. doi:

1078 https://doi.org/10.1016/j.jvolgeores.2004.10.021

1079

1080 Wright R, Blackett M, Hill-Butler C (2015) Some observations regarding the thermal flux from 1081 Earth's erupting volcanoes for the period of 2000 to 2014. Geophys Res Lett 4:282-289. 1082 https://doi.org/10.1002/2014GL061997

1083

1084 Zakšek K, Hort M, Lorenz E (2015) Satellite and Ground Based Thermal Observation of the 2014 1085 Effusive Eruption at Stromboli Volcano. Remote Sensing.7: 17190-17211. doi: $1086 \quad 10.3390 /$ rs 71215876.

1087

1088

1089

1090

1091

1092

1093

1094

1095

1096

1097

1098 
Table 1. Summary of the main features characterising Stromboli, Batu Tara and Tinakula volcanoes.

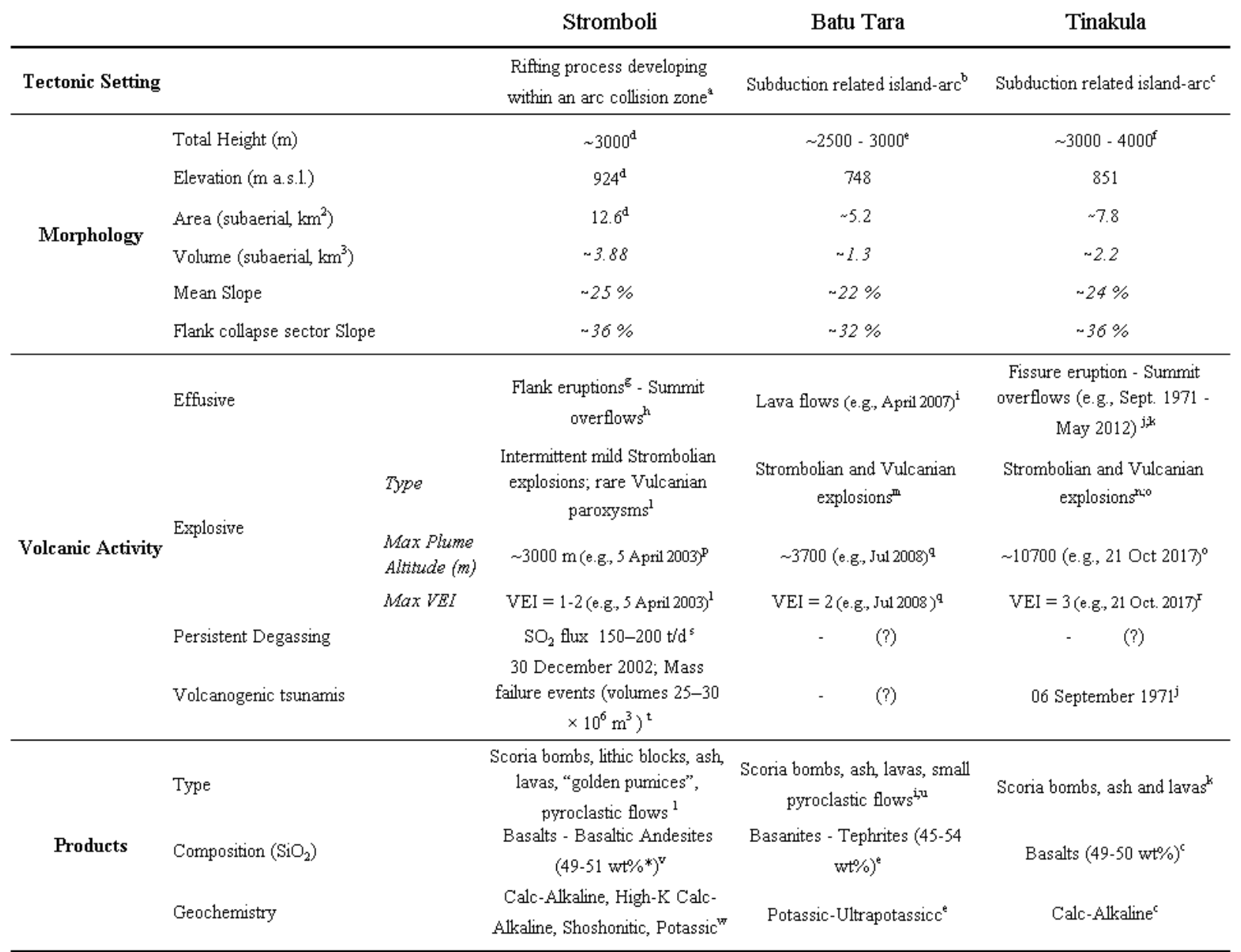

In Italics data retrieved from Google Earth Images; * identifiy $\mathrm{SiO}_{2}$ of the 2007-20141avas of Stromboli

a - Ventura (2013); b - Elburg et al. (2004); c - Schuth et al. (2004); d - Favalli et al. (2005); - Van Bergen et al. (1992); f - Davies et al. (1986); g - Barberi et al. (1993); h - Calvari et al. (2014); i - GVP (1971); k - GVP (2012); l - Rosi et al. (2013); m - GVP (2014); n - GVP (2003); o - GVP (2017); p - Pistolesi et al. (2011); q - GVP (2008); - GVP (2017); - Burton et al. (2009);

t - Marani et al. (2009); u - GVP (2016); v - Landi et al. (2009); w - Francalanci et al. (1999).

1100 Table 1. Summary of the main features characterising Stromboli, Batu Tara and Tinakula

1101 volcanoes, with data in italics retrieved from Google Earth Images. 

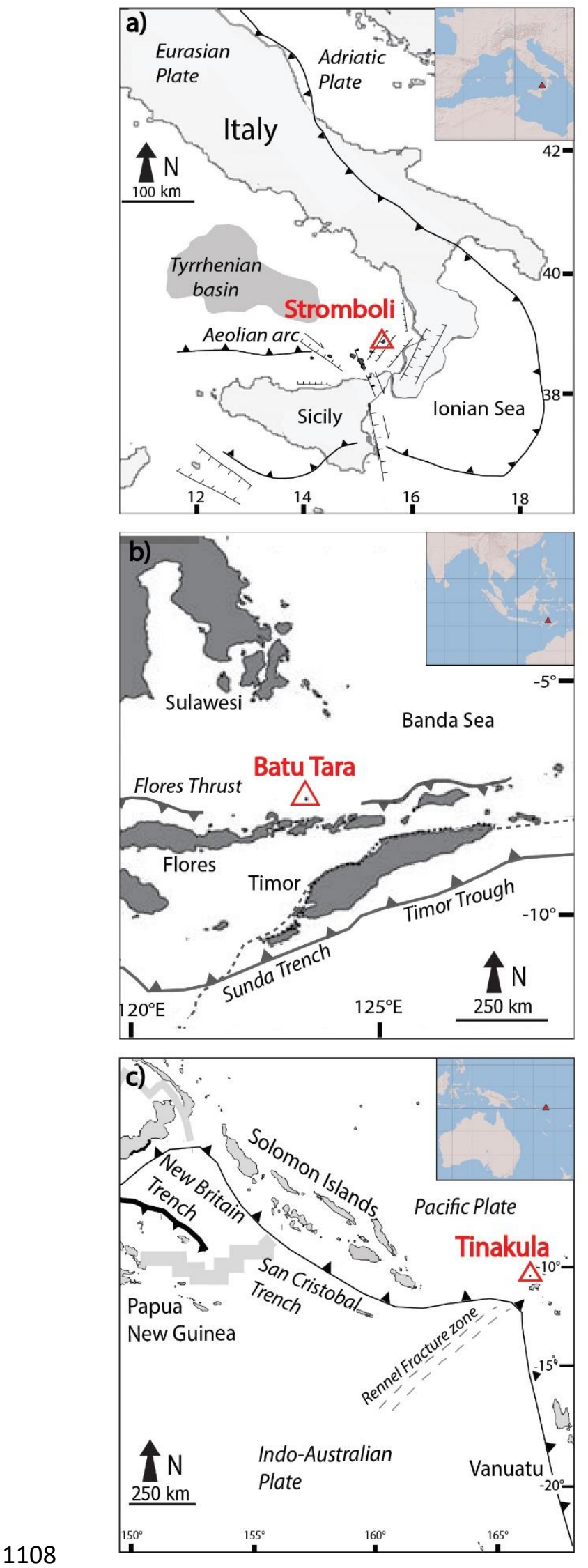
1109 Fig. 1 Simplified tectonic setting of the areas of (a) Stromboli, (b) Batu Tara and (c) Tinakula, 1110 after Ventura (2013), Elburg et al. (2007) and Davies et al. (2005), respectively. The insets indicate 1111 the world geographical position of the volcanoes.
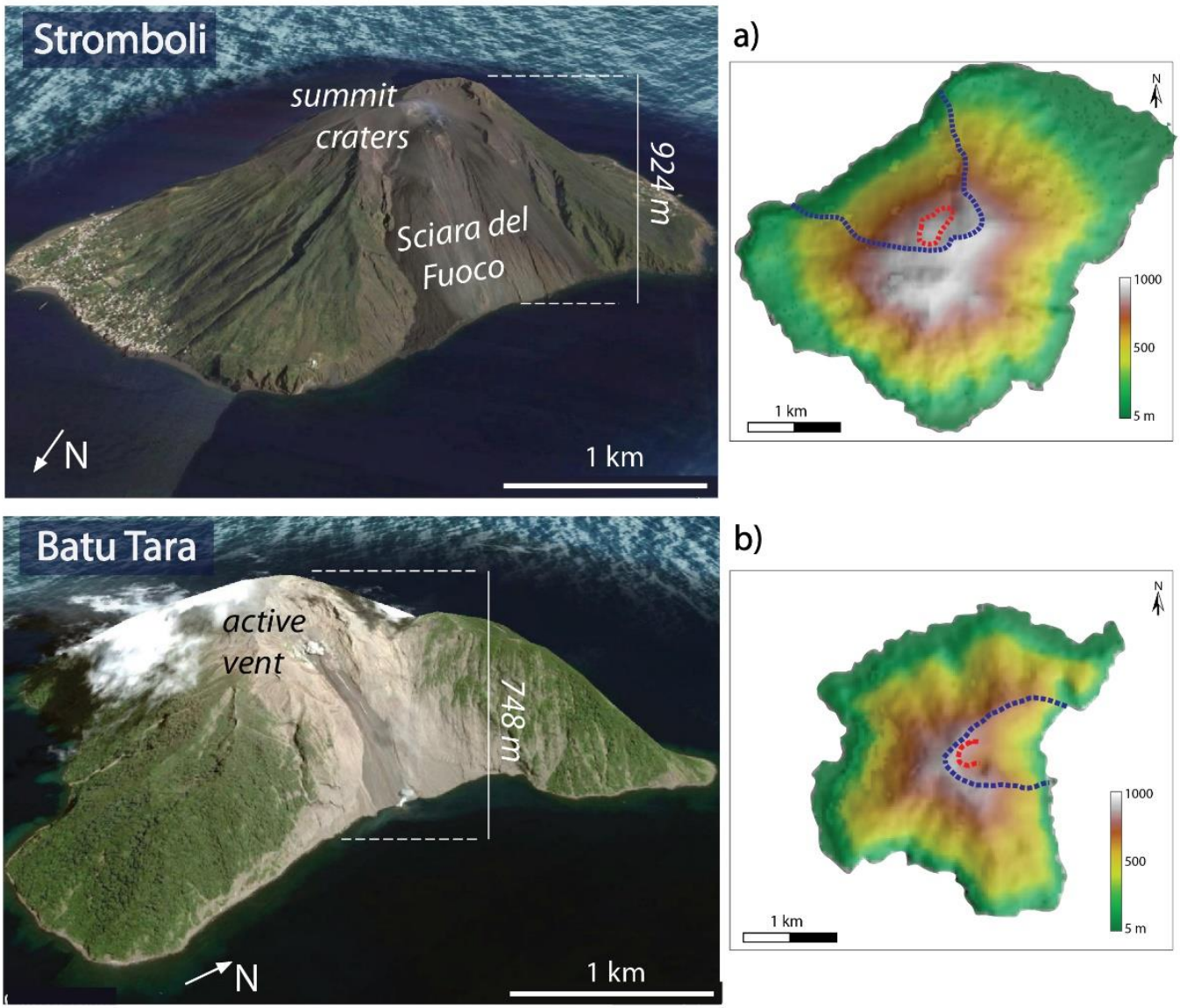

b)

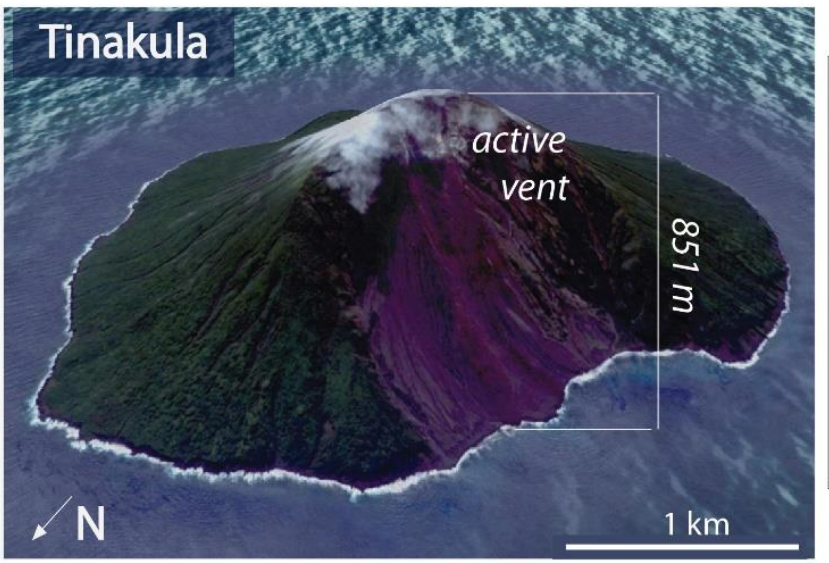

c)
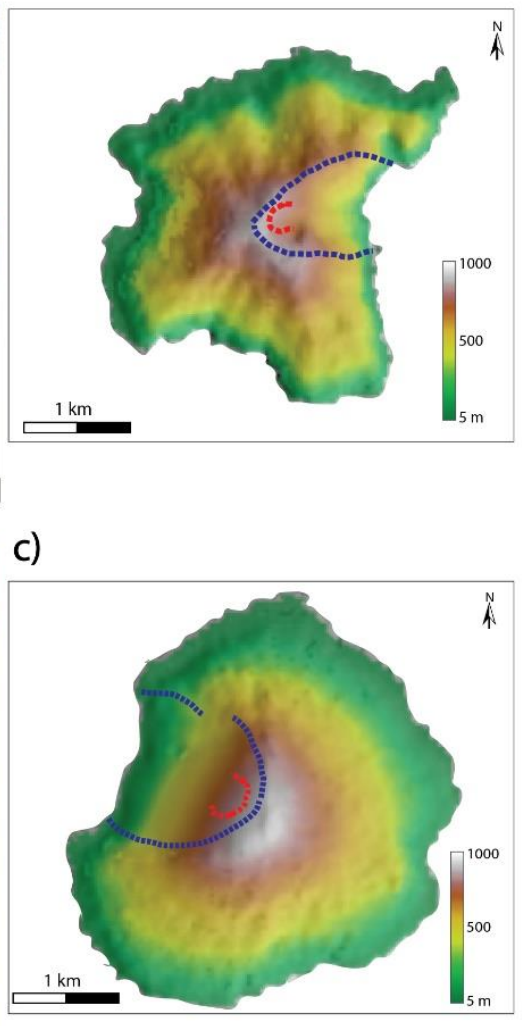
1114 Fig. 2 Google Earth views with elevation (meters above sea level) and crater(s) position, and 1115 associated 90-meter Digital Elevation Models (DEM) of the islands. Red lines denote the crater 1116 areas, and blue lines show the boundaries of flank scarps. Google Earth Images (C) Google and 1117 DigitalGlobe. DEMs derive from the NASA Shuttle Radar Topographic Mission (SRTM) database 1118 (Jarvis et al. 2008); products are freely available and downloadable by CGIAR-CSI, 1119 http://srtm.csi.cgiar.org.
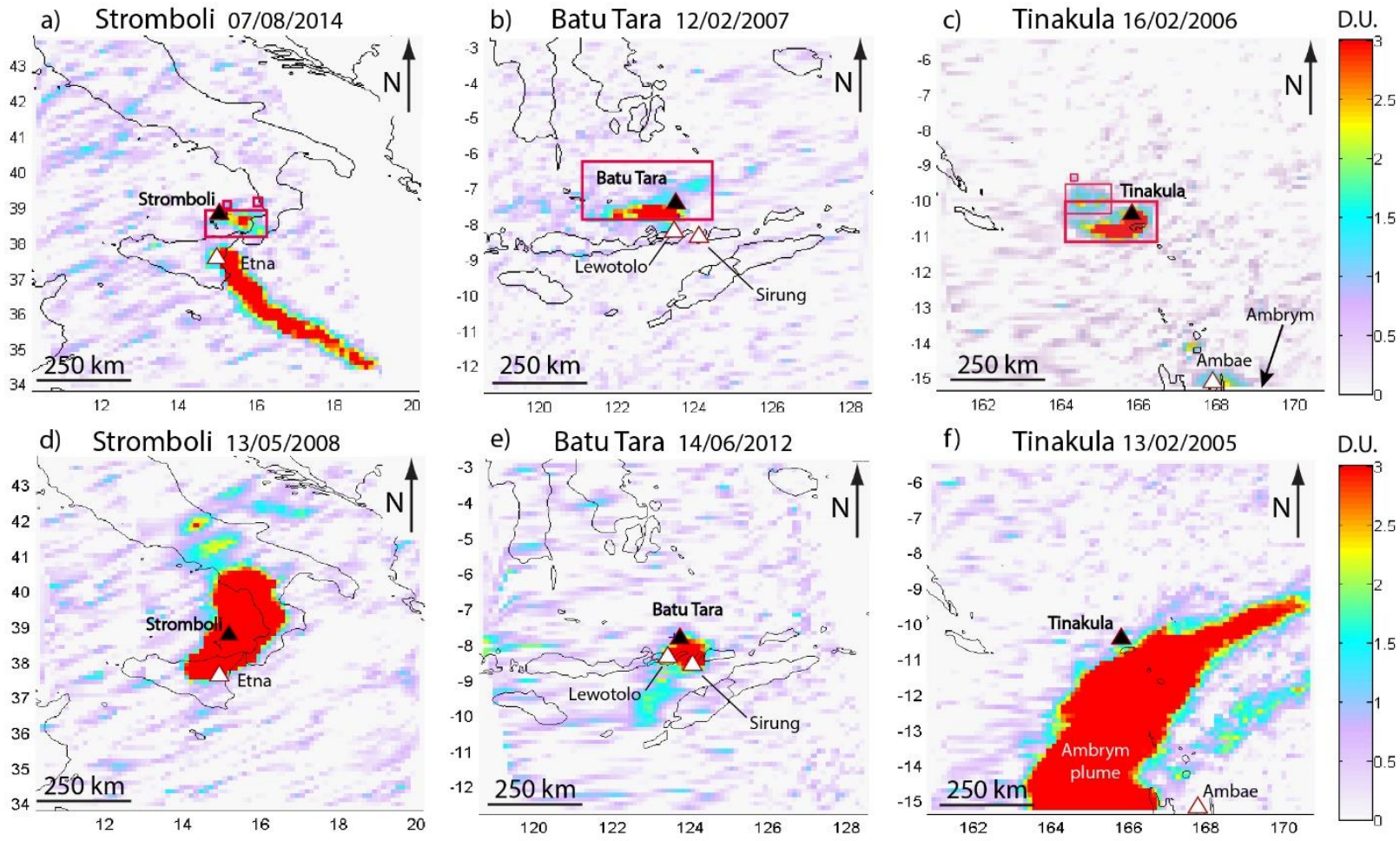

1122 Fig. 3 Examples of $\mathrm{SO}_{2}$ density maps at PBL layer (see Method Section) processed for Stromboli

1123 (a-d), Batu Tara (b-e) and Tinakula (c-f). Maps are centred on volcanoes and cover an area of $10^{\circ}$ $1124 \times 10^{\circ}$. Magenta rectangles (in a-b-c) represent the cluster(s) identified by the detection algorithm.

1125 The images d-e-f represent days where plumes belonging from adjacent volcanic sources (white 1126 triangles) contaminated the atmosphere of the target volcanoes (black triangles). 

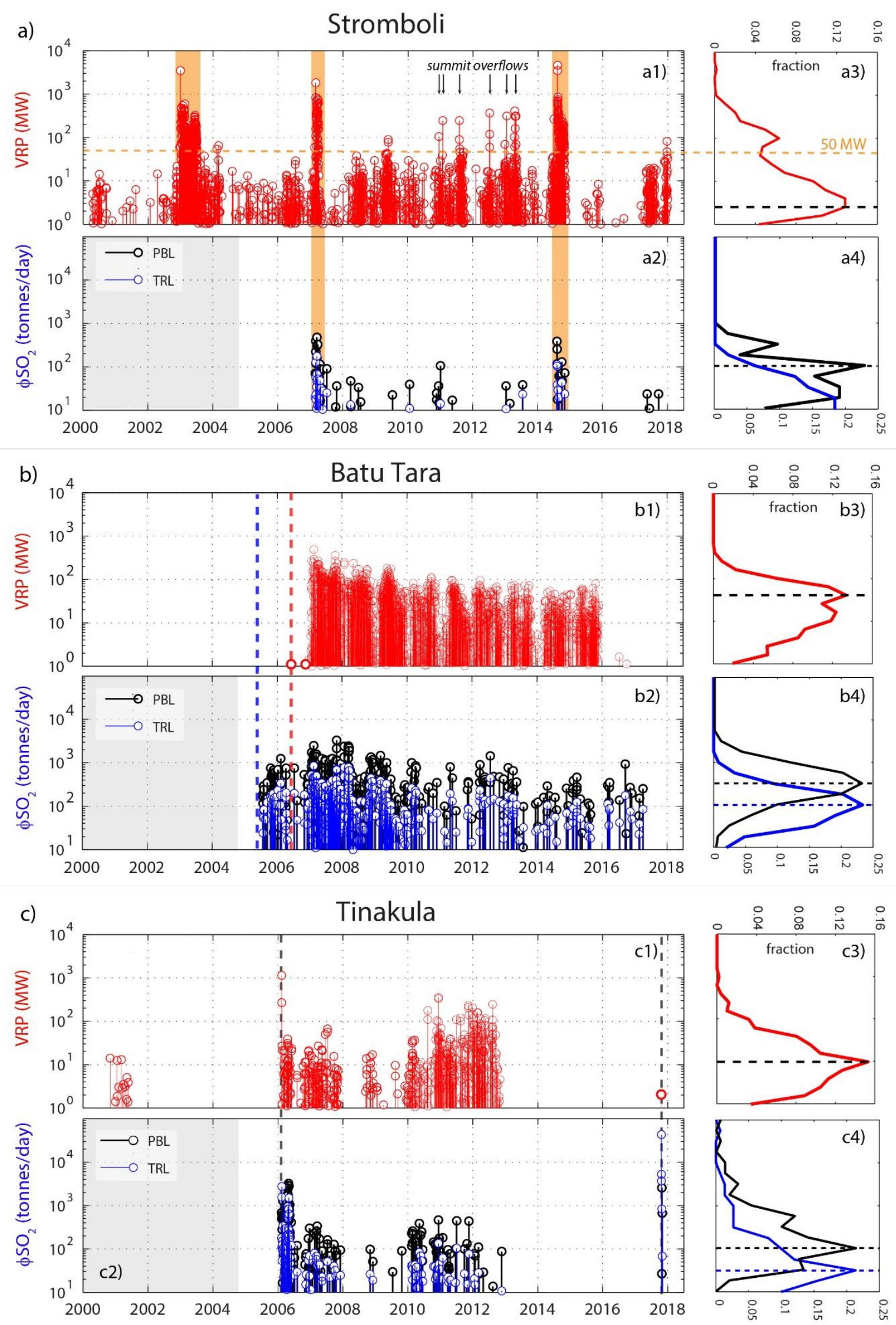
1129 Fig. 4\#1-2 2000-2017 VRP and $\phi \mathrm{SO}_{2}$ (on a logarithmic scale) time-series retrieved by processing 1130 MODIS images and OMSO2 Level2G data, at Stromboli (a), Batu Tara (b) and Tinakula (c). In 1131 (a), pale orange fields and minor black arrows represent, respectively, the main effusive phase and 1132 overflows episodes, while the horizontal orange dotted line marks the transition from strombolian

1133 to effusive regimes as indicated by Coppola et al. (2012). In (b), red and blue dotted lines mark 1134 the first detection on VRP and $\phi \mathrm{SO}_{2}$, respectively. In (c), main episodes of the 11 February 2006 1135 and 21 October 2017 have been reported with black dotted lines. \#3-4) represent the distribution 1136 of the log-scale values for $\operatorname{VRP}(\# 3)$ and $\phi \mathrm{SO}_{2}(\# 4)$. Blue and black lines show the $\phi \mathrm{SO}_{2}$ values at 1137 TRL and PBL levels, respectively; dotted lines mark the modal peak.
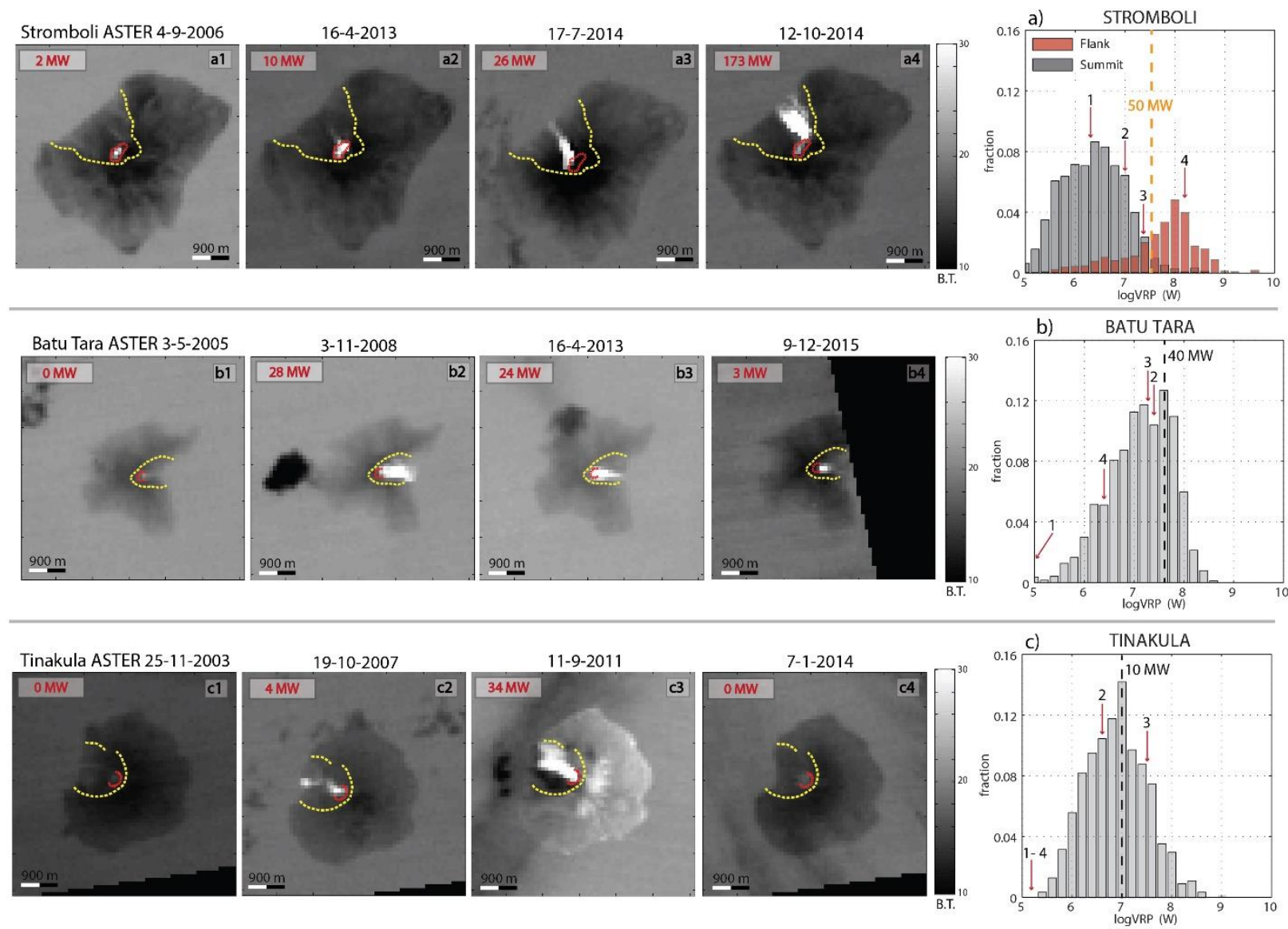
1140 Fig. 5 Histograms of the log-VRP data of the three volcanoes. The separation on flank and summit eruption at Stromboli has been obtained by using already reported lava flow duration (see Ripepe

1142 et al. 2017). The orange dotted line marks the transition from strombolian to effusive regimes at

1143 Stromboli; the black dotted lines mark the modal peak for Batu Tara and Tinakula; the red arrows

1144 indicate the four VRP-MODIS measurements corresponding to the selected ASTER images.

1145 ASTER images are shown in greyscale, with Brightness Temperature in the Band 13 (TIR region,

1146 10.25-10.95 $\mu \mathrm{m}$ ); MW values in red represent the corresponding MODIS heat flux measurement

1147 in the same ASTER acquisition (both sensors on Terra satellite). Red line marks the crater areas;

1148 yellow dotted line marks the boundaries of flank scarps.
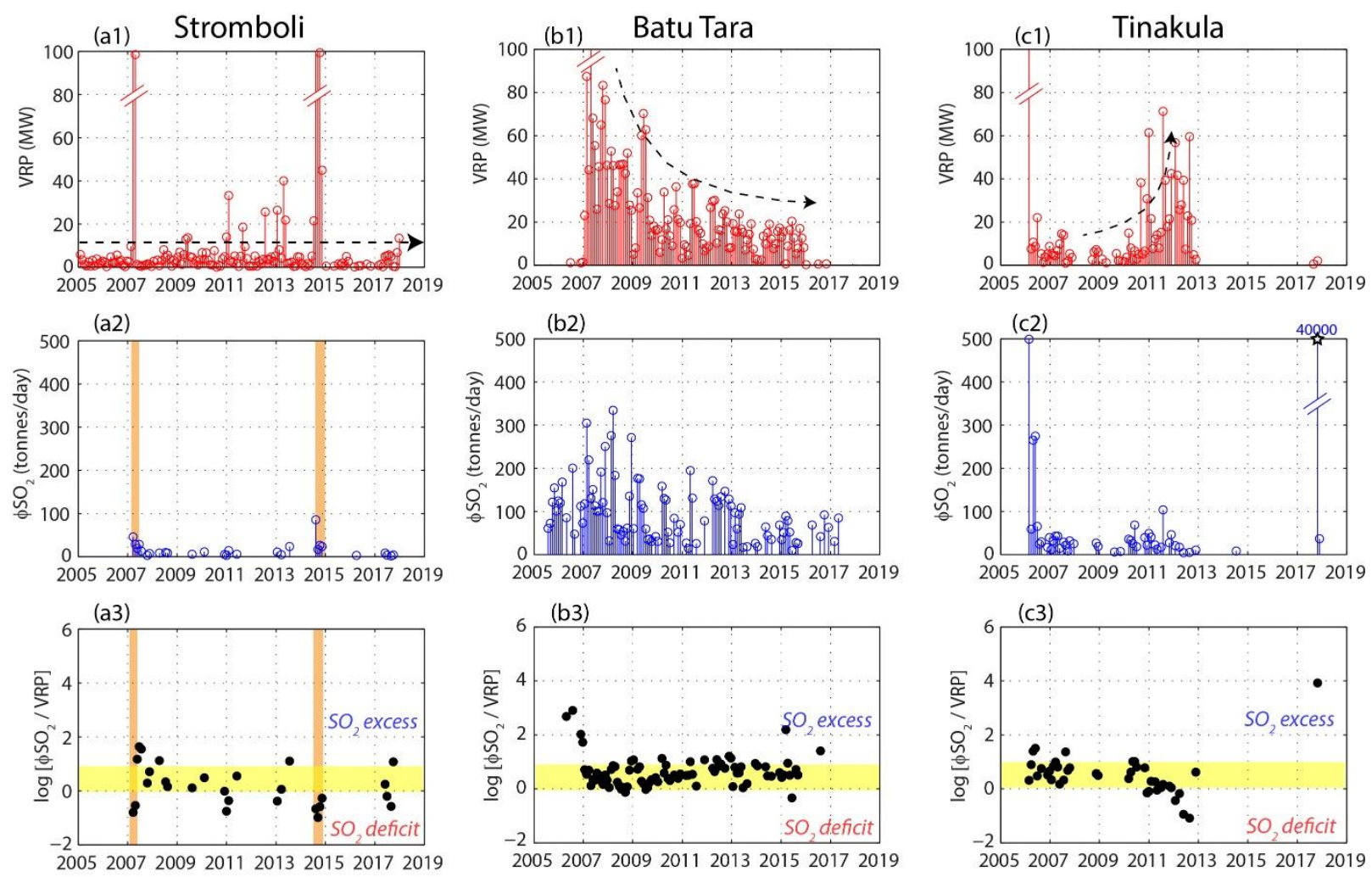

1151 Fig. 6 Time-series of the VRP (\#1), $\phi \mathrm{SO}_{2}$ (\#2) and $\phi \mathrm{SO}_{2} / \mathrm{VRP}$ (\#3) for (a\#) Stromboli, (b\#) Batu

1152 Tara and (c\#) Tinakula volcanoes. The orange field in (a2, 3) mark the effusive episodes. The 
1153 black star in (c2) represent the VEI 3 explosion of 21 October 2017. The black dashed line in (\#1)

1154 outlines the eruptive trend discussed in the text. The yellow band in (\#3) indicates the balanced

1155 range whereby the magma supply rate (sourcing the $\phi \mathrm{SO}_{2}$ ) and the magma output rate (sourcing

1156 the VRP) are equal: eruptions above or below this band may be considered as gas-rich or gas-poor,

1157 respectively.

1158
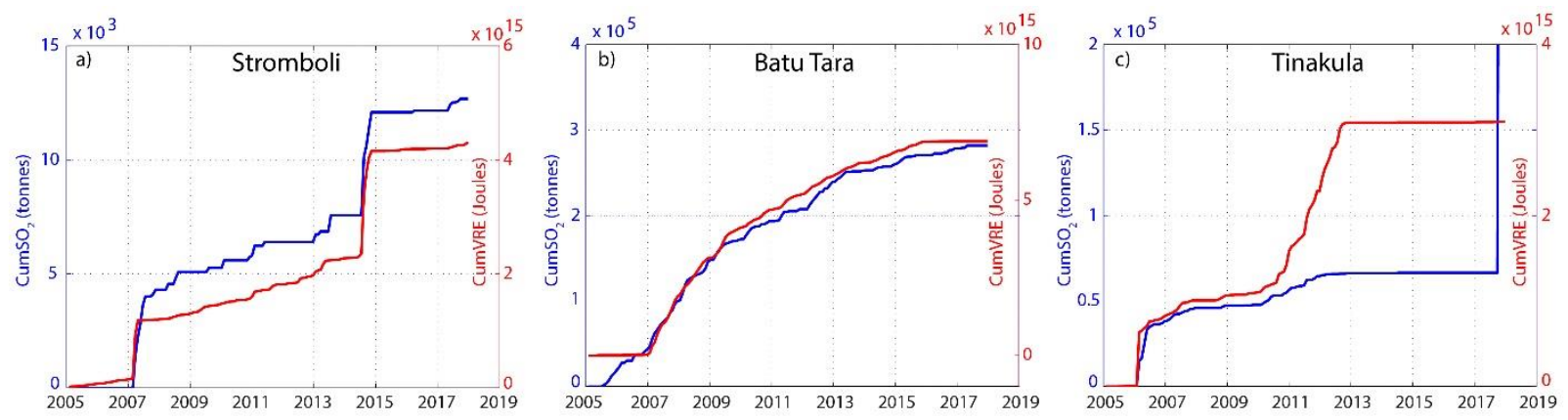

1160

Fig. 7 Cumulative thermal (CumVRE in Joules) and degassing ( $\mathrm{CumSO}_{2}$ in tonnes) emissions recorded between 2005 and 2017 at (a) Stromboli, (b) BatuTara and (c) Tinakula.
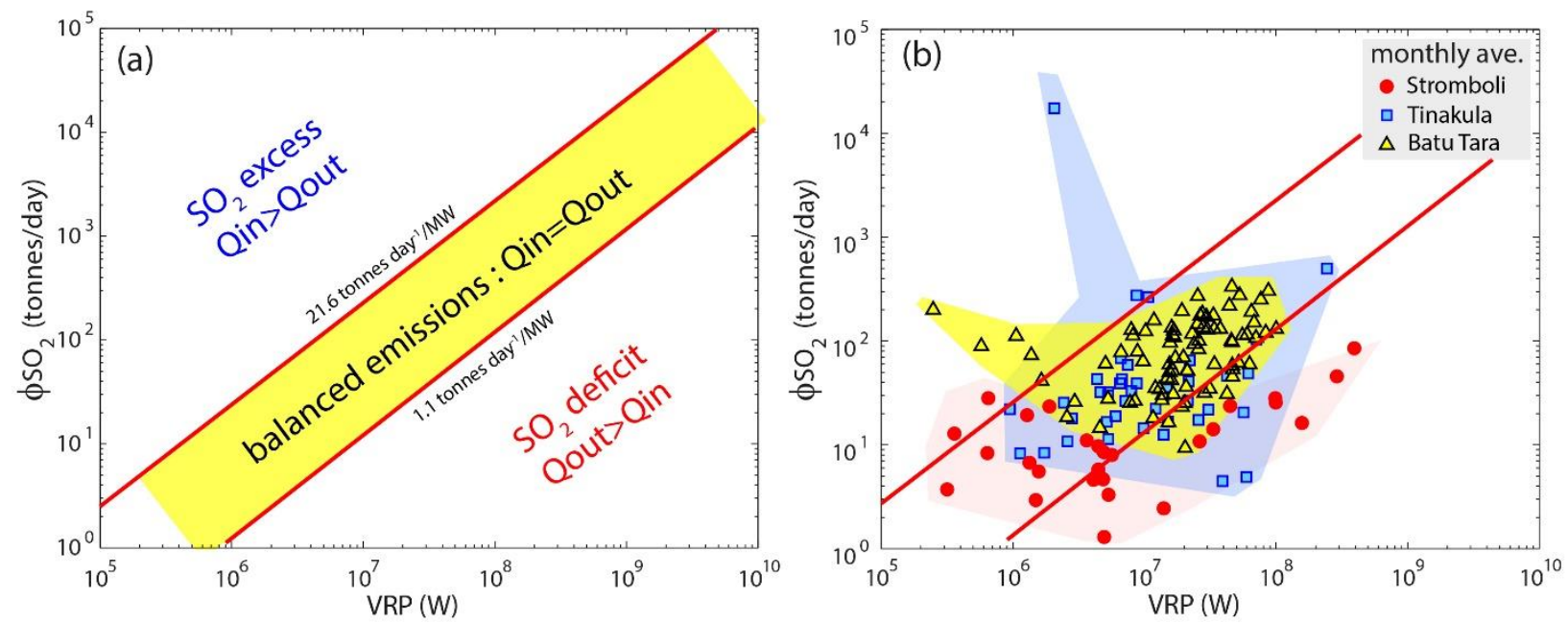

1164 Fig. 8 (a) Schematic plot showing the $\phi \mathrm{SO}_{2} / \mathrm{VRP}$ ratio for degassed/erupted magma budget. The

1165 yellow field (equation 3) describes the region of balanced emissions, whereby the the $\phi \mathrm{SO}_{2}$ and 
1166 the VRP are consistent with the eruption of all the degassed magma $\left(Q_{\text {in }}=Q_{\text {out }}\right)$. Emission ratios 1167 plotting outside the balanced region indicate a gas-rich (upper left) or gas-poor (lower right) 1168 eruption. (b) Monthly mean emissions for the volcanos on the $\phi \mathrm{SO}_{2} / \mathrm{VRP}$ framework. The red lines 1169 limit the balanced region. Shaded coloured fields perimeter the emission ratios for each volcano. 1170 Note how the highly energetic Stromboli's dataset (associated to flank eruptions) falls in the field 1171 of gas-poor eruption, while the single data point of Tinakula VEI 3 eruption of October 2017 falls 1172 in the gas-rich field. 